Makale Geliş | Received : 24.05.2019

Makale Kabul | Accepted : 25.07.2019

\title{
Toplumsalın Doğallaştırılması: Erken Evliliklerde Toplumsal Cinsiyet Algisı
}

\section{Naturalization of Social: Gender Perception in Early Marriages}

\section{Meyrem TUNA UYSAL* - Gizem TAN EREN** - Esma ŞİMŞEK***}

\author{
Süleyman Demirel Üniversitesi, Fen-Edebiyat Fakültesi, Sosyoloji Bölümü, meyremtuna@sdu.edu.tr * \\ Süleyman Demirel Üniversitesi, Fen-Edebiyat Fakültesi, Sosyoloji Bölüm, gizemeren@s,sdu.edu.tr ** \\ Süleyman Demirel Üniversitesi, Fen-Edebiyat Fakültesi, Sosyoloji Bölüm, esma.simsek094@gmail.com *** \\ ORCID Numaraları | ORCID Numbers: 0000-0001-8910-8058* - 0000-0001-6669-8411** - 0000-0001- \\ $6194-4521^{* * *}$
}

\begin{abstract}
ÖZ
Erken yaşta evlilikleri meşrulaştıran mekanizmalar ya da dinamikler ataerkil sistem ve geleneksel toplum yapısının ürünüdür. Bu sistemin ürünü olan erken evliliklerle birlikte kadın-erkek arasında eşit olmayan ilişkiler ortaya çıkmakta ve kadına yönelik bakış açısından kaynaklı bu eşitsizlik daha da artmaktadır. Özellikle erken evliliklere erkek çocuklarına nazaran daha çok kız çocuklarının maruz kalması bu durumun en önemli göstergelerinden biridir. Araştırma, erken evlilik yapan kadınların toplumsal cinsiyet algısını ele almaktadır. Araştırmanın amacı, 18 yaşından küçük ve evlilik gerçekleştiren kadınların kendi ifadelerinden hareketle erken evliliğe ilişkin toplumsal cinsiyet rollerinin nasıl kurgulandığını, evliliklerinde yaşadıkları zorlukları, evlilik beklentilerini, rol paylaşımı sırasında yaşanan toplumsal cinsiyet eşitsizliğinin neler olduğunu diğer bir deyişle toplumsal cinsiyet algısını ortaya koymaktır. Buradan hareketle araştırma, Ağrı ilinde 15 kadın katılımcı ile yarı-yapılandırılmış bir görüş̧e formu kullanılarak ve derinlemesine görüşmeler yapılarak gerçekleştirilmiştir. Bu çerçevede araştırma erken evlilik yapan kadınlara uygulanarak onların toplumsal cinsiyet rollerini ele alması bakımından önem taşımaktadır. Araştırma sonucunda erken evliliklerle birlikte kadına yönelik toplumsal cinsiyet eşitsizliği daha da artmakta ve bu kadınlar cinsiyet rolleri bakımından ikincil konuma düşmektedir.
\end{abstract}

Anahtar Kelimeler: Erken Evlilik, Toplumsal Cinsiyet, Kadınlık, Annelik

\begin{abstract}
Mechanisms and dynamics that legitimizes early marriages are product of patriarchy and traditional social structure.. The unequal relationships between women and men emerge and this inequality from the point of view of women increases along with the marriages which are the product of this mentality The exposure of girls to early marriages more than boys, is an important sign of this situation. The study tackles the gender perceptions of early married women.The aim of this study is to examine the gender roles according to the own expressions of women who have been married under the age of 18 ,and to the expressions of gender roles in marriage, difficulties in marriage, expectations from the marriage, inequality in role sharing, in other words show the gender perception.Hence, the research was carried out by using a semi-structured interview form and making in-depth interviews with 15 female participants in Ağrı.In this context, research is important in terms of addressing women's gender roles by applying them to early marriages.As a result of the research, gender inequality towards women increases with early marriages and these women falls into secondary position in terms of gender roles Key Words: Gender, Early Marriage, Femininity, Maternity.
\end{abstract}




\section{Giriş}

Ataerkil zihniyet ve geleneksel değerler, kadın ve erkek arasındaki toplumsal cinsiyet algısının farklılık göstermesine neden olmaktadır. Bunun temelinde toplum içerisinde kadın ve erkeğe atfedilen sosyo-kültürel anlamlar ve değerler yatmaktadır. Kadın ve erkek arasındaki eşitsizlik, ataerkil toplum yapısı ve bu yapıdaki kültürel değerler aracılığıyla üretilmekte, nesilden nesile aktarılmaktadır.

Her ne kadar cinsiyet rolleri toplumdan topluma farklılık gösterse de genel olarak toplumsal cinsiyet rolleri erkeklere nazaran daha çok kadınlar açısından dezavantajlılık anlamına gelmektedir. Geleneksel toplumlarda kadın ve erkek arasındaki eşit olmayan toplumsal ilişkiler, erkekleri kamusal alana yönlendirirken, kadınları özel alana doğru itmektedir. Birçok toplumda "kadının yeri kocasının yanıdır" gibi düşünceler hâkimdir. $\mathrm{Bu}$ yüzden de kadınlar için en uygun yerin evi olduğu düşünülmektedir. Özellikle erken evliliklerle birlikte bu kalıp yargılar kadınların eşitsiz konumunu daha da pekiştirmektedir. Dolayısıyla ataerkil zihniyet kadını ikincilleştirmekte, erkek akranlarıyla aynı yetenek ve beceriye sahip olmadığı düşünülen kız çocukları çocuk yaşta evlendirilmektedir.

Her toplumsal katmanda ya da sınıfta görülebilen bu durum az gelişmiş ülkelerde daha yaygındır. Sosyal ve kültürel etkiler, dini gerekçeler, eğitim düzeyinin düşüklüğü, toplumsal cinsiyet eşitsizliği, ekonomik eşitsizlik, yoksulluk vb. gibi etkenler erken evliliğin nedenleri arasinda yer almaktadir (UNICEF, 2012, s. 6).

Erken evliliklere hem kız çocukları hem de erkek çocukları maruz kalmakla birlikte kız çocuklarının erken yaşta evlenmesi erkeklere oranla daha fazladır. Gelenek adı altında meşru hale getirilerek doğallaştırılan erken evlilikler toplumsal cinsiyet eşitsizliğinin en bariz örneklerinden biridir. Bu durum kadının toplum içerisindeki konumuyla alakalıdır. Örneğin ataerkil toplum yapısına sahip birçok toplumda erkek çocukları soyun devamı olarak görülürken kız çocukları erken yaşta evlendirilerek onlardan çocuk yaşta anne olmaları ve ev içi rolleri üstlenmeleri beklenmektedir. Genellikle eşlerinden daha genç olan, eğitim ve yaşam tecrübesi az olan kız çocukları evlilik sürecinde eşlerine bağımlı hale gelmektedirler. Yaşamları üzerinde çok az söz sahibidirler. Kadın ve erkek arasındaki bu eşitsiz ilişki, erken evlilik yapan kız çocuğunun eşi, eşinin ailesi tarafından sözlü ya da fiziksel istismara uğrama riskini artırmaktadır. Bu duruma hazır olmayan kız çocukları ise istismara, aile içi şiddete, psikolojik rahatsızlıklara açık hale gelmektedir.

Erken evliliği deneyimlemiş kadınların toplumsal cinsiyete yönelik algılarını ele almayı amaçlayan bu çalışmada, kadınların toplumsal cinsiyete yönelik kadınlık ve erkeklik algıları, rol tanımlamaları irdelenmektedir. Nitekim erken evliliği deneyimlemiş kadınların toplumsal cinsiyet rollerine ilişkin yükledikleri anlamlar ve deneyimler önem taşımaktadır. Çünkü içinde bulunulan sosyo-kültürel ve ekonomik özelliklerin de etkisi göz önünde bulundurulursa erken evlilik yapan kadınların toplumsal cinsiyete ilişkin rollerinde toplumsal yapının belirleyici olmaktadır.

$\mathrm{Bu}$ çerçeveden hareketle çalışma, amaçlı örneklem kullanılarak seçilen erken evliliği deneyimlemiş 15 kadın katılımcı ile derinlemesine görüşmeler sonucu elde edilen veriler doğrultusunda tartışılmaktadır. Erken evliliği deneyimlemiş kadınların hem kendilerine hem de erkeklere yönelik toplumsal cinsiyet rollerini nasıl tanımladıkları, erken evlilikle birlikte ev içi rol ve sorumlulukları üstlenme noktasında ne gibi zorluklar yaşadıkları, kadınlara yüklenen toplumsal cinsiyet rollerinin evlilik yaşantısında ne gibi sonuçlar doğurduğu ve yine kendi anlatılarından hareketle toplum tarafından nasıl tanımlandıklarına ilişkin sorunsallar doğrultusunda kadınlara yönelik bakış açısı ve kadınlık rolleri, annelik ve çocuk bakımı, erkeklere yönelik bakış açısı ve erkeklik rolleri, babalık ve çocuk bakımı temaları elde edilen verilerden hareketle konu ile ilişkilendirilerek ele alınmaktadır. Bu çerçevede söz konusu çalışma, erken evlilik yapan kadınların toplumsal cinsiyete özgü rolleri nasıl tanımladıklarına, düşüncelerine ve deneyimlerine odaklanmaktadır. 


\section{Toplumsal Cinsiyet Bağlamında Erken Evlilikler: Kavramsal Bir Giriş}

Birleşmiş Milletler Çocuk Haklarına Dair Sözleşme'nin (1989), 1.Maddesine göre “Bu sözleşme uyarınca çocuğa uygulanabilecek olan kanuna göre daha erken yaşta reşit olma durumu hariç, onsekiz yaşına kadar her insan çocuk sayılır." denilmektedir. Bu bağlamda onsekiz yaşın altında yapılan evlilikler "erken evlilik", "çocuk evliliği"; evlenen kadın ise "çocuk gelin", "çocuk anne" gibi terimlerle nitelendirilmektedir (Orçan ve Kar, 2008, s. 98). Bununla birlikte Türk Medeni Kanunu'nun 124. Maddesinde yer alan "Erkek veya kadın on yedi yaşını doldurmadıkça evlenemez. Ancak, hâkim olağanüstü durumlarda ve pek önemli bir sebeple on altı yaşını doldurmamış olan erkek veya kadının evlenmesine izin verebilir..." ifadesiyle de onyedi yaşını doldurmadan yapılan evlilikler 'erken evlilik' olarak kabul edilmekte; onaltı yaşını doldurmuş kız ve erkek çocuklarının evliliği hâkim kararıyla mümkün kılınmaktadır. Çocuk Koruma Kanunu ise "daha erken yaşta ergin olsa bile, 18 yaşını doldurmamış kişı”yi çocuk olarak tanımlamaktadır. Böylece hukuk sisteminde Türk Medeni Kanunu'na göre 17, Türk Ceza Kanunu'na göre 15 ve Çocuk Koruma Kanunu'na göre 18 yaşını doldurmadan önce evlilik yapan kız çocuklarının 'çocuk gelin' olarak kabul edilmesi gibi çelişkili bir durum ortaya çıkmaktadır (Calp, 2014, s. 7; Gezer Tuğrul, 2018, s. 6; Boran, Gökçay, Devecioğlu ve Eren, 2013, s. 58). Buradan hareketle erken evlilikler çocuk hakları bakımından bir insan hakkı ihlalini ifade etmektedir.

Erken evlilikler ile erkek çocuklarına nispeten kız çocuklarının daha erken yaşta evlendirilmesi ve bu evliliklerin kız çocukları açısından daha ciddi sorunlar yaratması literatürde konu ile ilgili çalışmaların daha fazla kız çocukları üzerine yoğunlaşmasına neden olmaktadır (Aydemir, 2001, s. 1).

Toplumda önemli çocuk ve kadın sorunlarından biri olan erken evlilikler, toplumsal cinsiyet rolleri bakımından kadınların duygu ve düşüncelerinin bastırıldığı, kadın-erkek arasındaki ilişkilerin sosyal ve kültürel olgular temeline inşa edildiği bir eylem olarak ifade edilmektedir (Kara, 2015, s. 64). "Baba evinden telli duvaklı gelinlikle çıkmak, iyi bir eş ve anne olmak, küçük yaşta evlendirilip çok çocuk doğurmak, çocuk bakımı" gibi kadınlara biçilen roller toplumsal baskı unsuruna dönüşerek kız çocuklarını erken yaşta evliliğe sürüklemektedir (Gezer Tuğrul, 2018, s. 5, 8). Bu evliliklerle kadınların toplum içindeki eşitsiz konumları pekiştirilmektedir. Buna karşın geleneksel ve ataerkil özelliklere sahip toplumlarda erken evlilikler bir sorun olarak görülmemektedir. Çünkü toplumsal uzlaşıyla meşruluk kazanan erken evlilikler, bu toplumlarda normalleştirilmektedir (Aydemir, 2001, s.1). Nitekim gelenek adı altında sıradanlaştırılarak yapılan bu evlilikler zamanla geleneksel toplum içerisinde kadınlar tarafından içselleştirilerek doğallaştırılmaktadır.

Toplumsal cinsiyet rolleri bağlamında ataerkil ve geleneksel toplum yapısının kadın ve erkekten beklediği roller farklılaşmaktadır. Nitekim toplumsal cinsiyet rolleri, kadınlığın ve erkekliğin kültürel beklentileri de kapsayacak şekilde toplumsal ortamlarda ifade ediliş şeklidir (Dökmen, 2004, s. 18). Buna göre cinsiyet rolleri, içinde bulunulan toplum içerisinde kadınlara ve erkeklere düşen rol ve sorumluluklar ile onların nasıl davranmaları gerektiğini ortaya koymaktadır (Marshall, 1999, s. 100-101). Nitekim bireyin içinde yaşadığı toplumun sosyo-kültürel özellikleri, kadın ve erkek arasındaki ilişkileri, onların nasıl davranacağına, nasıl hareket edeceğine ve nasıl düşüneceğine ilişkin beklentileri toplumsal olarak ortaya koymaktadır. Diğer bir ifadeyle bireyler doğduğu andan itibaren toplumsal cinsiyetlerine özgü roller çerçevesinde toplumsal rol ve sorumlulukları öğrenerek büyümekte ya da bu roller toplum tarafından zorla öğretilmeye çalışılmaktadır. Böylece kadınlar, ev işleri, çocuk bakımı gibi özel alana doğru itilirken erkekler ev dışı rolleri ve sorumlulukları üstlenerek özel alanın dışına yönelmektedirler (Günay ve Bener, 2011, s. 3). Örneğin ataerkil yapıda erkeğin evini geçindirmesi kadının ise çocuk bakımını ve ev işlerini üstlenmesi beklenir. $\mathrm{Bu}$ durum 
erkekleri eğitime, istihdama katılmayı teşvik ederken tam tersine kadınları ev içine hapsederek onları evliliğe yönlendirmektedir (Yüksel-Kaptanoğlu ve Ergöçmen, 2012, s. 135). Dolayısıyla geleneksel bakış açısıyla kendi ailesi içerisinde emanet olarak görülüp hiç okula gönderilmeyen ya da eğitimlerini yarıda bırakmak zorunda kalan kız çocukları erken yaşta evlendirilerek eğitim haklarından yoksun bırakılmaktadırlar (Gezer Tuğrul, 2018, s. 9$10)$.

Kadınların eğitim haklarından yararlanmalarına izin vermeyen ataerkil değerlerin sonuçlarından biri de erkeklere oranla kadınların eğitim düzeyinin düşük olmasıdır. Erken evliliklerin hem nedeni hem de sonucu olan eğitim düzeyinin düşüklüğü kadınların kamusal alana katılımı açısından en önemli göstergelerden biridir. Çocuk yaşta evlilik ve eğitim düzeyinin düşük olması kadınları kamusal alandan özel alana doğru iterek onların özel alanlarında bile daha az söz sahibi olmalarına neden olmaktadır (UNICEF, 2005, s. 1). Dolayısıyla toplumda kadın ve erkeğe biçilen rollerdeki eşitsizlikleri iki kat arttıran erken evliliklerle toplumsal cinsiyet eşitsizliği daha da artmaktadır.

Kısacası içinde yaşanılan toplumun sosyo-kültürel özellikleri ve ataerkil zihniyet çerçevesinde erken evlilikle birlikte kadın-erkek arasındaki toplumsal cinsiyet eşitsizliği daha da artmakta ve kadınlar rol ve sorumlulukların paylaşımı noktasında çifte sömürüye uğrayarak ikincilleştirilmektedirler.

\section{Dünyadaki Erken Evliliklerin Görünümleri}

Erken evlilik sorununu ele alırken ayı zamanda söz konusu toplumun sosyo-kültürel ve ekonomik dinamiklerinin ele alınarak değerlendirilmesi gerekmektedir (Aydemir, 2001, s. 5). Özellikle ülkelerin gelişmişlik düzeyleri ve sosyo-ekonomik durumları bu evliliklerin ortaya çıkmasında etkili olan faktörlerden biridir (Yüksel ve Yüksel, 2014, s. 20). Nitekim küresel bir sorun olan erken evliliklerin görüldüğü yerlere bakıldığında genellikle az gelişmiş ya da gelişmekte olan ülkeler karşımıza çıkmaktadır. Buna göre ülkelerin gelişmişlik düzeyi ile erken evlilik oranları arasında anlamlı bir ilişkinin olduğu söylenebilir (Aydemir, 2001, s. 8).

\section{Tablo-1: Ülkelerde Görülen Erken Evlilik Oranları}

\begin{tabular}{|l|l|l|}
\hline Ülke & Erkek (\%) & Kadın (\%) \\
\hline ABD & 1,3 & 3,9 \\
\hline Kanada & 0,3 & 1,3 \\
\hline Almanya & 0,1 & 1,2 \\
\hline Fransa & 0,1 & 0,6 \\
\hline Ingiltere & 0,5 & 1,7 \\
\hline Hollanda & 0,2 & 2,4 \\
\hline İtalya & 0,9 & 3,1 \\
\hline Belçika & 0,2 & 1,6 \\
\hline Azerbaycan & 3,2 & 12,0 \\
\hline Arjantin & 2,7 & 12,4 \\
\hline Türkiye & 4,3 & 15,5 \\
\hline Venezuela & 5,5 & 17,7 \\
\hline Irak & 14,9 & 27,9 \\
\hline Hindistan & 9,5 & 37,5 \\
\hline Nepal & 13,5 & 41,6 \\
\hline & &
\end{tabular}




\begin{tabular}{|l|l|l|}
\hline Afganistan & 9,2 & 53,7 \\
\hline Nijer & 4,2 & 61,9 \\
\hline
\end{tabular}

Kaynak: United Nations. (2000). World Marriage Patterns, 2000. Polulation DivisionDepartment Of Economic And Social Affairs. www.un.org/en/development/desa/population/publications/pdf/family/marriage-patterns.pdf

Tablodan da görüldüğü üzere dünyada erken evlilik oranları ülkeden ülkeye farklılık gösterse de bu evliliklerin nedenleri arasında bir yandan ekonomik sorunlar bir yandan da ataerkilliğin hakim olduğu geleneksel uygulamalar yer almaktadır. Dolayısıyla ataerkil ve geleneksel toplum yapısının hakim olduğu ve ekonomik gelişmişlik düzeyi bakımından da düşük olan toplumlarda erken evlilik oranları artmaktadır (Gezer Tuğrul, 2018, s. 7). Örneğin, Nijer'deki 36 köyde yapılan bir çalışmada kız çocuklarının erken yaşta evlilikle birlikte ekonomik bakımdan daha iyi bir konuma gelecekleri ve böylelikle toplumsal statülerini arttıracakları yönünde sonuçlar elde edilmiştir (PLAN-UK, 2011).

Birçok ülkede erkek ve kız çocukları erken ve zorla evliliğe karşı yasal bir korumaya sahip değillerdir. Örneğin, Afrika, Orta Doğu ve Latin Amerika'daki ülkelerde yasal evlilik yaşı 14 yaşına kadar inebilmektedir. Toplumsal cinsiyet eşitsizlikleri de yasal sistemler üzerindeki etkileriyle erken evliliğe katkıda bulunmaktadır. Nijer ve Hindistan gibi erken evlilik oranlarının yüksek olduğu bazı ülkelerde, erkek ve kız çocukları arasında sadece cinsiyetlerinden dolayı bir eşitsizlik söz konusudur. Erkek akranlarıyla aynı eşitliğe sahip olmadığ 1 için, kız çocukları erkek çocuklarına nazaran daha az değere sahiptir. Bu durum da kız çocuklarının erkek çocuklarından daha erken yaşta evlenmeye uygun olduğu ve evliliğin kız çocuğunun refahını sağlamanın en önemli yolu olduğu düşüncesini güçlendirmektedir (PLAN-UK, 2011).

Her ne kadar ekonomik ve sosyo-kültürel özellikler farklılık gösterse de birçok ülkede toplumsal cinsiyet rolleri her yaşta kadının toplum içerisinde eşitsizliğini daha da arttırmaktadır. Özellikle ataerkil toplumlarda kültürel değerler ve geleneksel söylemler, toplumsal cinsiyete özgü kalıp yargılar sonucunda kız çocukları çocuk yaşta ev içi rollere hazır olmadıkları halde evlilikle birlikte birçok sorumluluk almak zorunda kalmaktadır.

Türkiye’ deki Erken Evliliklerin Görünümleri

Dünyanın farklı ülkelerindeki kadar yüksek olmasa da Türkiye'de de erken evlilikler yüksek orandadır. Ancak Türkiye'nin her yerinde görülebilen bu evliliklerin oranları ülkenin batısından doğusuna doğru gidildikçe değişmektedir. Özellikle Doğu Anadolu ve Güneydoğu Anadolu bölgelerinde görülen erken evliliklerin nedenlerini ele alırken bu bölgelerin gerek sosyo-ekonomik gerekse de sosyo-kültürel özelliklerini göz önünde bulundurmak gerekmektedir (Arslan, 2015, s. 11). 
Tablo-2: Bölgelere Göre İlk Evlenme Yaşı, TAYA 2006-2011 (\%)

\begin{tabular}{|l|l|l|l|l|l|l|l|}
\hline & $\mathbf{2 0 0 6}$ & \multicolumn{2}{l|}{$\mathbf{2 0 1 1}$} \\
\hline & $\begin{array}{l}\mathbf{1 8} \text { yaş } \\
\text { altı }\end{array}$ & $\mathbf{1 8 - 2 4}$ & $\mathbf{2 5 - 2 9}$ & $\begin{array}{l}\mathbf{1 4} \text { yaş } \\
\text { altı }\end{array}$ & $\mathbf{1 5 - 1 7}$ & $\mathbf{1 8 - 2 4}$ & $\mathbf{2 5 - 2 9}$ \\
\hline İstanbul & 12,6 & 60,6 & 22,0 & 2,2 & 11,6 & 57,4 & 21,2 \\
\hline Batı Marmara & 15,4 & 61,1 & 18,3 & 1,4 & 11,9 & 60,7 & 21,5 \\
\hline Ege & 17,9 & 59,0 & 19,1 & 2,1 & 14,9 & 56,9 & 21,1 \\
\hline Doğu Marmara & 18,1 & 61,8 & 17,1 & 1,6 & 13,6 & 58,5 & 20,2 \\
\hline Batı Anadolu & 18,8 & 62,0 & 15,6 & 2,3 & 15,7 & 59,1 & 17,5 \\
\hline Akdeniz & 18,4 & 55,2 & 19,9 & 2,7 & 13,9 & 53,3 & 23,2 \\
\hline Orta Anadolu & 25,6 & 58,7 & 13,9 & 2,8 & 19,8 & 59,2 & 15,2 \\
\hline Batı Karadeniz & 24,0 & 58,7 & 14,2 & 2,1 & 16,8 & 59,5 & 17,2 \\
\hline Doğu Karadeniz & 22,6 & 58,5 & 15,0 & 2,2 & 16,1 & 57,2 & 19,0 \\
\hline Kuzeydoğu Anadolu & 27,0 & 53,2 & 16,7 & 1,7 & 18,4 & 56,1 & 18,9 \\
\hline Ortadoğu Anadolu & 28,9 & 53,8 & 14,2 & 4,2 & 19,4 & 55,5 & 17,3 \\
\hline Güneydoğu Anadolu & 25,4 & 59,4 & 12,6 & 4,9 & 20,2 & 53,3 & 17,6 \\
\hline
\end{tabular}

\section{Kaynak:}

https://www.tuseb.gov.tr/enstitu/tacese/yuklemeler/ekitap/aile/60_aile yapisi arastirmasi 201 3.pdf

Tablodan da anlaşılacağı üzerine Türkiye'de erken evlilik oranlarına bakıldığında 2006 ve 2011 yılları arasında yapılan araştırmada bölgeler arası farklılıklar ortaya çıkmaktadır. Buna göre 2006 yılında Ortadoğu Anadolu (\%29) ve Kuzeydoğu Anadolu'da (\%27) 18 yaşın altında evlenme oranı diğer bölgelere oranla yüksekken, İstanbul (\%13) ve Batı Marmara'da (\%15) bu oran düşmektedir. Benzer şekilde 2011 yılında yapılan araştırmada erken evlenme oranı İstanbul ve Batı Marmara'da düşükken 2006 yılın tersine bölgeler arası farklılıklar ortaya çıkmıştır. 2011 yılında 18 yaşın altında evlenme oranının en yüksek olduğu bölgeler sirasiyla Güneydoğu Anadolu (\%25), Ortadoğu Anadolu (\%24) ve Orta Anadolu'dur (\%23) (Turğut ve Feyzioğlu, 2014, s. 124).

Yukarıdaki verilerden hareketle, ataerkillik ve gelenekselliğin hakim olduğu birçok ülkede olduğu gibi Türkiye'de de erken yaşta evlilik sorununun önemini koruduğu söylenebilir. $\mathrm{Bu}$ toplumlardaki yapısal özellikler erken evlilikleri bir sorun olarak görmemekte, gelenek adı altında kültür aracılığıyla yeniden üretilerek içinde bulunulan toplumun bir gerekliliği ya da zorunluluğu olarak değerlendirilmektedir. Özellikle kız çocuklarının erken yaşta evliliğe daha çok maruz kalmasında özellikle kırsal alanlarda kabul gören geleneksel toplumun değer yargıları ön plana çıkmaktadır. Gelenekselliğin baskın olduğu toplum yapısında kız çocukları erken yaşta evlendirilerek kendi aileleri yerine eşleri ve eşlerinin ailelerinin kontrolü altına girmekte ve bu da kültürel bir değer olarak meşrulaştırılmaktadır. (Yüksel Kaptanoğlu ve Ergöçmen, 2012, s. 151-152).

Tablo-3: Cinsiyete Göre İlk Evlenme Yaşı, TAYA 2006-2011 (\%)

\begin{tabular}{|l|l|l|l|l|}
\hline & Erkek & Kadın & Erkek & Kadın \\
\hline Yaş & \multicolumn{2}{|l|}{$\mathbf{2 0 0 6}$} & $\mathbf{2 0 1 1}$ \\
\cline { 1 - 3 } $\mathbf{1 4}$ yaş altı & \multirow{2}{*}{6,5} & \multirow{2}{*}{31,2} & 0,6 & 4,1 \\
\cline { 1 - 3 } $\mathbf{1 5 - 1 7}$ & & 5,2 & 23,9 \\
\hline $\mathbf{1 8 - 2 4}$ & 58,5 & 59,5 & 54,0 & 59,7 \\
\hline
\end{tabular}


Meyrem TUNA UYSAL - Gizem TAN EREN - Esma ŞiMŞEK

\begin{tabular}{|l|l|l|l|l|}
\hline $\mathbf{2 5 - 2 9}$ & 28,5 & 7,6 & 31,6 & 9,4 \\
\hline $\mathbf{3 0 - 3 4}$ & 5,1 & 1,2 & 6,8 & 2,0 \\
\hline $\mathbf{3 5 - 3 9}$ & 1,4 & 0,5 & 1,3 & 0,5 \\
\hline $\mathbf{3 9 +}$ & - & - & 0,5 & 0,3 \\
\hline
\end{tabular}

Kaynak:

https://www.tuseb.gov.tr/enstitu/tacese/yuklemeler/ekitap/aile/60_aile_yapisi_arastirmasi_201 3.pdf

Türkiye'deki erken evlilikler cinsiyete göre değerlendirildiğinde 2006 yılında yapılan araştırmada kadın ve erkeklerin evlenme yaşları dikkat çekmektedir. Erkeklerin \%7'si 18 yaşın altında evlilik gerçekleştirirken bu oran kadınlarda \%31'e yükselmektedir. 2011 yılında ise ilk evlenme yaşı 14'ün altında olan kadınların oranı \%4 iken; ilk evlenme yaşı 15-17 olan kadınların oranı \%24'tür. Bu oranlar Türkiye'de "çocuk gelin" olgusu olarak tartışılan erken evlilikler için önemli bir veri sunmaktadır. İlk evlenme yaşı 18 'in altında olan erkeklerin oranı ise \%6'dır. (Turğut ve Feyzioğlu, 2013, s. 121). Bu oran ele alındığında ise erken evliliklere daha çok kız çocukları maruz kalsa da erkek çocuklarının da erken yaşta evlendirildiği ve “çocuk damat"ların da göz ardı edilmemesi gereken önemli bir konu olarak ele alınması gerektiği vurgulanmalıdır.

TUİK'in en son yaptığ çocuklarındaki resmi evlenmelerin oranı \%6,2 iken 2017 yılında bu oran \%4,2'ye düşmüştür. İl bazında değerlendirildiğinde ise 2017 yılında kız çocukların erken yaşta evliliklerinin oranı Ağrı ili \%16,6 ile en üst sırada yer alırken bu ili sırasıyla Muş $(\% 16,1)$ ve Bitlis $(\% 12,3)$ izlemektedir. Erken yaşta evlenen kız çocuklarının en düşük olduğu iller ise sırasıyla; Tunceli $(\% 0,4)$, Rize $(\% 1,1)$ ve Trabzon $(\% 1,4)$ olmuştur (TUIK, 2018). Buna göre erken evliliklerin diğer bölgelere nazaran daha çok Doğu Anadolu ve Güneydoğu Anadolu bölgelerinde görüldüğü söylenebilmektedir.

Türkiye'de evlilik, kanunlar tarafından belirlenen kurallar çerçevesinde resmi nikâh adı altında gerçekleştirilmektedir. Buna karşılık erken evliliklerin çoğu resmi olmayan dini nikâh yoluyla yapılan evliliklere dayanmaktadır (Aydemir, 2001, s. 11). Çünkü taraflar reşit olmadığı için resmi nikah kıyılamayan erken evliliklerde çoğunlukla bu durum resmi kurumlardan gizlenmektedir. Dolayısıyla bu evliliklerde dini nikâh meşru olarak kabul edilmektedir. Dini nikâhla çocuklarını erken yaşta evlendiren aileler bunu gelenek adı altında sıradanlaştırmaktadır. Çünkü Türkiye'de erkek çocuklarına nazaran kız çocuklarının erken yaşta evlendirilmesinde manevi kültür öğeleri etkili olmaktadır. Ataerkil yapı içerisinde yaşamını sürdüren toplumun gelenek, görenek, örf adet gibi kültür unsurları, onların değerlerini, tutumlarını, tercihlerini şekillendirmekte dolayısıyla erken evlilikler kültürel bir uygulama olarak kabul görmektedir (Diyaplığlu, Yıldırım ve Purutçuoğlu, Tarihsiz).

Kandiyoti (1988)'ye göre Türkiye'deki ataerkil yapı ve kuşakların bir arada yaşadığı geniş aile içerisinde toplumsal cinsiyet temelli normlar ve erken evliliklerle birlikte kadınların eşitsiz konumu artmaktadır. Örneğin ataerkil yapı içerisinde kadınlara öğretilen toplumsal cinsiyet rolleri erken evliliğin meşrulaşmasını ve devamını sağlayan, pekiştiren önemli tartışma konularından biridir. Bu süreçte kadının yeri özel alanla sınırlandırılarak kız çocuğunun evlenmesi, hamile kalması, anne olması, çocuk bakımı, eşine kadınlık yapması ve eşinin ailesinin tüm ev içi işlerini yerine getirmesi normal kabul edilmektedir (Burcu, Yıldırım, Sırma ve Sanıyaman, 2015). Böyle bir sistemde kadın ve erkek arasındaki eşitsiz konum daha da artmaktadır. Dolayısıyla kadın-erkek arasındaki eşitsiz bu durum kadın üzerinde baba ya da koca iktidarının yanı sıra toplumsal bir baskı aracına dönüşsebilmektedir.

\section{ARASTTIRMANIN YÖNTEMI}

Araştırmada, Ağrı ilinde gerçekleşen erken evliliklerde toplumsal cinsiyet rollerinin nasıl kurgulandığı üzerinde durulmaktadır. Bu yüzden çalışmada nitel araştırma yöntemi 
kullanılarak katılımcıların sosyal dünyaları ve konuya dair anlamlandırmaları ele alınmaktadır. Araştırma, 2019 yılı Şubat ve Nisan ayları arasında 15 kadın katılımcı ile yarıyapılandırılmış görüşme formu kullanılarak gerçekleştirilmiştir. Nitel araştırma olarak tasarlanan çalışmada derinlemesine yüz yüze görüşmeler yapılarak veriler toplanmıştır. Görüşmeciler amaçlı örneklem kullanılarak araştırma sorusu ve amacına uygun biçimde seçilmiştir. Görüşmecilere kartopu yöntemiyle ulaşılmıştır. Görüşmelerin öncesinde katılımcılar ile ön görüşmeler yapılarak güvenleri kazanılmaya çalışılmış ve araştırmanın amacı açıklanmıştır. Görüşmeler sırasında katılımcıların izinleri doğrultusunda ses kayıt cihazı kullanılmış olup iki katılımcının ses kayıt cihazı kullanımına izin vermemesi nedeniyle bu katılımcılarla yapılan görüşmelerde ayrıntılı notlar alınmıştır. Ayrıca görüşme sırası ve görüşme sonrasındaki izlenimler de not edilmişstir.

Araştırma verilerinin analizinde öncelikle ses kayıtlarının transkripsiyonu gerçekleştirilmiş ve veriler düzenli bir şekilde bir araya getirilmiştir. Ardından verilerin indirgenmesi, sunulması ve sonuçların betimlenmesi şeklindeki aşamalar (Miles ve Huberman, 1994) doğrultusunda veri analizi gerçekleştirilmiştir. Analiz sürecinde, veriler sürekli okunarak düzenlenmiş ve belirli temalar etrafında kategorize edilerek yorumlanmıştır (Creswell, 2013). Bu doğrultuda söz konusu çalışmada, erken evlilik yapan kadınların söylemlerinden hareketle toplumsal cinsiyete dair algılamaları ortaya çıkartılarak, kadın ve erkeğe özgü toplumsal cinsiyet rollerini nasıl meşrulaştırdıkları çözümlenmiştir. Bu çerçevede görüşmeler erken evlilik yapan kadınların kendi hikâyelerinden yola çıkarak kadınlık rolleri, annelik ve çocuk bakımı süreçleri, buna karşılık yine kadınların anlatılarından hareketle erkeklik rolleri, babalık ve çocuk bakımına dair söylemsel tanımlamaları olmak üzere toplam dört tema altında kategorize edilerek tartışılmıştır. Kategorize edilen bu temalar, görüşmelerden elde edilen bulgulara dayanmaktadır ve temalar etrafında yorumlamalar yapılırken bu bulgulara sadık kalınmıştır. 


\section{Araştırma Bulgularının Değerlendirilmesi}

\section{- Demografik Özellikler}

Tablo-4: Katılımcıların Demografik Özellikleri

\begin{tabular}{|c|c|c|c|c|c|c|c|c|c|c|c|}
\hline & Yaş & $\begin{array}{l}\text { Medeni } \\
\text { Durum }\end{array}$ & $\begin{array}{c}\text { Eğitim } \\
\text { Durumu }\end{array}$ & Mesleği & $\begin{array}{c}\text { Gelir } \\
\text { Durumu }\end{array}$ & $\begin{array}{c}\text { Kardeş } \\
\text { Sayısı }\end{array}$ & $\begin{array}{l}\text { Çocuk } \\
\text { Sayısı }\end{array}$ & $\begin{array}{c}\text { Evlenme } \\
\text { Yaşı }\end{array}$ & $\begin{array}{c}\text { Eşinin } \\
\text { Evlenme } \\
\text { Yaşı }\end{array}$ & $\begin{array}{c}\text { Annesinin } \\
\text { Evlenme } \\
\text { Yaşı }\end{array}$ & $\begin{array}{c}\text { Babasının } \\
\text { Evlenme } \\
\text { Yaşı }\end{array}$ \\
\hline K1 & 30 & Evli & İlkokul & Ev Hanımı & $2500 \mathrm{TL}$ & 6 & 3 & 17 & 28 & $17-18$ & 25 \\
\hline K2 & 46 & Evli & İlkokul & Ev Hanımı & $\begin{array}{c}2500- \\
3000 \mathrm{TL}\end{array}$ & 16 & 4 & 16 & 24 & 13 & 26 \\
\hline K3 & 28 & Evli & $\begin{array}{c}\text { İlkokul } \\
\text { Terk }\end{array}$ & Ev Hanımı & $5000 \mathrm{TL}$ & 9 & 3 & 17 & 23 & $16-17$ & $19-20$ \\
\hline K4 & 36 & Evli & Ortaokul & Ev Hanımı & $3600 \mathrm{TL}$ & 10 & 2 & 17 & 32 & 16 & 20 \\
\hline K5 & 40 & $\begin{array}{c}\text { Boşanmış- } \\
\text { Bekar }\end{array}$ & İlkokul & Yaşlı Bakımı & $\begin{array}{c}2000- \\
2500 \mathrm{TL}\end{array}$ & 11 & 3 & 17 & 18 & $12-13$ & $20-21$ \\
\hline K6 & 27 & Evli & Ortaokul & Ev Hanım1 & $2000 \mathrm{TL}$ & 7 & 2 & 16 & 26 & 14 & 24 \\
\hline K7 & 19 & Evli & İlkokul & $\begin{array}{c}\text { Temizlik } \\
\text { İșleri }\end{array}$ & $\begin{array}{c}1000- \\
1500 \mathrm{TL}\end{array}$ & 7 & 2 & 15 & 18 & $12-13$ & $20-21$ \\
\hline K8 & 35 & Evli & Ortaokul & Ev Hanımı & $2000 \mathrm{TL}$ & 6 & 4 & 17 & 18 & 13 & 18 \\
\hline K9 & 38 & $\begin{array}{c}\text { Boşanmış- } \\
\text { Bekar }\end{array}$ & Üniversite & $\begin{array}{c}\text { Özel } \\
\text { Güvenlik } \\
\text { Görevlisi }\end{array}$ & $2000 \mathrm{TL}$ & 7 & 3 & 15 & 35 & 15 & 25 \\
\hline K10 & 41 & Evli & İlkokul & Ev Hanımı & $\begin{array}{l}\text { Belli } \\
\text { değil }\end{array}$ & 10 & 4 & 16 & Bilmiyor & $\begin{array}{c}2 \text { anne. } \\
\text { Kendi } \\
\text { annesi } 17\end{array}$ & 16 \\
\hline K11 & 40 & $\begin{array}{c}\text { Boşanmış- } \\
\text { Evli- } 2 . \\
\text { Evlilik }\end{array}$ & Üniversite & Sekreter & $\begin{array}{c}2000- \\
2500 \mathrm{TL}\end{array}$ & 7 & 2 & 15 & 26 & 14 & 25 \\
\hline K12 & 32 & Evli & İlkokul & Ev Hanımı & $\begin{array}{c}3500- \\
5000 \mathrm{TL}\end{array}$ & 8 & 6 & 16 & 31 & 16 & 13 \\
\hline K13 & 32 & Evli & $\begin{array}{l}\text { İlkokul } \\
\text { Terk }\end{array}$ & Pazarlamacı & $5000 \mathrm{TL}$ & 7 & 3 & 15 & 25 & $\begin{array}{c}\text { Bilmiyor } \\
\text { (18'den } \\
\text { önce) } \\
\end{array}$ & Bilmiyor \\
\hline K14 & 44 & Evli & Lise & Ev Hanımı & $\begin{array}{c}2500- \\
3000 \mathrm{TL}\end{array}$ & 5 & 3 & 16 & 18 & 17 & 22 \\
\hline K15 & 30 & Evli & Ortaokul & Ev Hanımı & $3000 \mathrm{TL}$ & 6 & 3 & 16 & 29 & 22 & 24 \\
\hline
\end{tabular}

Araştırmada katılımcıların demografik özellikleri bağlamında sosyo-kültürel ve ekonomik açıdan önemli olarak görülen yaş, medeni durum, eğitim durumu, meslek, gelir durumu, kardeş sayısı, çocuk sayısı, evlenme yaşı, eşin ve ebeveynlerin evlenme yaşları gibi unsurlara yer verilmiştir.

Tablo-4'e göre, araştırmaya katılan kadın katılımcıların demografik özellikleri incelendiğinde, şu anki yaşlarının 19-44 arasında çeşitlilik gösterdiği ve kadın katılımcıların on üçünün evli olduğu görülmüştür. İki katılımc1 ise eşinden boşanmıştır. Evli olan kadın katılımcılardan biri de erken evliliği gerçekleştirdiği eşi ile boşanmış olup ikinci evliliğini yapmıştır. Eğitim durumlarına bakıldığında ise kadın katılımcıların ikisinin ilkokul terk, altısının ilkokul, dördünün ortaokul, birinin lise ve ikisinin de üniversite mezunu olduğu görülmüştür. Buna göre erken evliliğin önemli nedenleri arasında yer alan eğitim faktörü ele alındığında katılımcılarının eğitim düzeylerinin düşük olduğu görülmektedir. Eğitim düzeyinin düşüklüğü katılımcıların aile yapısı, ekonomik durumu ve yaşadıkları toplumun sosyo-kültürel özellikleri teşvik edici rol oynamakla birlikte 'kadının yeri kocasının yanıdır' düşüncesinden hareketle de kız çocuklarının eğitimine önem verilmediği ve erken yaşta evlendikleri ya da evlendirildikleri görülmektedir. Eğitim ile ilgili bu özelliklerden hareketle, sosyo-kültürel açıdan kız çocuklarının eğitim seviyelerinin düşük olmasının normal görüldüğü ve bir sorun teşkil etmediği sonucuna varılabilmektedir. Diğer yandan, on katılımcı ev hanımıdır. Dolayısıyla bu katılımcılar sadece özel alan içerisinde yer almaktadırlar. Beş katılımcının ise kamusal alanda yer alarak yaşı bakımı, temizlik, güvenlik görevliliği, sekreterlik, pazarlamacılık gibi işleri gerçekleştirdikleri görülmektedir. Katılımcıların gelir 
düzeyleri de buna paralel olarak 1000TL ile 5000TL arasında değişmektedir. Katılımcıların kendileri de dahil olmak üzere kardeş sayıları 5 ile 16 arasında çeşitlilik göstermektedir. Onların geniş aile yapısına sahip olduklarını gösteren bu durum aynı zamanda katılımcıların ailelerinde çok eşliliğin olması (K10, 41 yaşında, evlenme yaşı 16) ile de açıklanabilir. Dolayısıyla sosyo-kültürel açıdan kalabalık aile yapısı ve çok eşlilik meşru görülmektedir. Ancak, bu duruma karşıt bir şekilde katılımcıların çocuk sayısı 2 ile 4 arasında değişmektedir. $\mathrm{Bu}$ ise aile yapısında küçülmeye doğru gidildiğini gösterir niteliktedir.

Tablo-4'e göre, katılımcıların evlilik yaşları incelendiğinde ise dördünün 15, altısının 16 ve beşinin de 17 yaşında evliliklerini gerçekleştirdikleri görülmüştür. Kadın katılımcıların eşlerinin evlilik yaşlarının ise 18 yaş ve üstü olduğu belirtilmiştir. Buna göre, kadın katılımcıların eşlerinin erken evlilik gerçekleştirmediği ve yaş olarak katılımcılardan büyük oldukları sonucuna varılabilmektedir. Dolayısıyla bu durum erken yaşta evliliğe erkek çocuklarına nazaran kız çocuklarının daha çok maruz kaldığını gösterir niteliktedir. Ayrıca ebeveynlerinin evlilik yaşlarına bakıldığında ise katılımcıların hepsinin annesinin buna karşılık sadece iki katılımcının babasının erken evlilik gerçekleştirdiği görülmüştür. Dolayısıyla kadın katılımcıların ebeveynleri arasında da evlilik gerçekleşirken yaş farkı bulunduğu ve babalarının annelerinden daha büyük olduğu sonucuna varılabilmektedir. $\mathrm{Bu}$ durumda katılımcıların evlilik yaşları ile annelerinin evlilik yaşları arasında bir paralellik olduğu ve sosyo-kültürel yapının kadının erken evliliğini meşru kıldığı söylenebilmektedir. Buna göre katılımcıların demografik özelliklerinden ve anlatılarından hareketle ataerkil aile yapısı ve geleneksel uygulamalar erken yaşta evliliği sıradanlaştırmakta ve içinde bulunulan toplum tarafindan bu durum kabul görmektedir

\section{Toplumsal Açıdan Kadınlara Yönelik Bakış Açısı ve Kadınlık Rolleri}

Bireylerin toplumsal cinsiyetlerine özgü roller çerçevesinde kadın ya da erkek olarak nasıl davranacağını, nasıl hareket edeceğini ve nasıl düşüneceğini içinde bulunulan toplumun sosyo-kültürel özellikleri belirlemektedir (Terzioğlu ve Taşkın, 2008, s. 63). Araştırma kapsamında kadınlara yönelik bakış açısı ve kadınlık rolleri incelendiğinde öncelikle katılımcıların kendilerini kadın olarak nasıl değerlendirdikleri ele alınmaktadır. Böylelikle onların gözünden bir kadının nasıl olması gerektiği ve kendi kadınlık algıları anlaşılmak istenmektedir.

Kadın katılımcıların, kadınlara yönelik düşüncelerine bakıldığında 'toplumsal baskı'nın hakim olduğu görülmektedir. Otuz altı yaşında bir katılımc1; "kadın, evin her şeyidir. Kadın güçlü olmalı ki evdekiler huzurla yaşayabilsin. Kadın evin huzurunu sağlayan kişidir. Kadın olmazsa ev çöker. ...Açıkçası kadınlar daha çok hizmet etmek için varmış gibi düşünülür. Erkeğe hizmet etsin, çocuğa baksın, eve baksın, evin bütün işlerini yapsin, gerektiği yerde erkeğe kadınlık yapsın. yani işte bu tür şeyler kadından beklenir. ...Toplumda hep bu gözle baklyorlar kadina..." (K4, 36 yaşında, evlenme yaş1 17) ifadesiyle kadınlar üzerinde sosyo-kültürel yapının belirleyiciliğine vurgu yapmaktadır. İçinde bulunulan sosyokültürel yapı ekseninde kadınlar, sosyal yaşam ve evlilik yaşantısı noktasında toplumsal açıdan baskılanmaktadırlar. $\mathrm{Bu}$ da kadın katılımcıların tanımlamalarında kadınların yaşamlarının özel alanla sınırlı olması, evliliğin sürdürülmesi ve boşanmış bir kadın olmamak gibi gerekliliklerin vurgulanmasına neden olmaktadır. Kırk yaşında başka bir katılımcı "kadınları çok hor görüyorlar. Özellikle eşinden ayrllan kadınlara kötü gözle bakıyorlar. Dünyanın en adi şeyi kadınlar olarak görüyorlar. Ben kimseye boşanmışım diyemiyorum, kim sorsa "Eşim İstanbul'da çalışlyor." diyorum. Çünkü bir yere gitsen filan hemen başka teklifler ediyorlar, kötü gözle bakıyorlar sana..." (K5, 40 yaşında, evlenme yaşı 17) diyerek boşanma hususunda namus kavramına vurgu yapmaktadır. Boşanmış bir kadın, toplumsal açıdan baskı ile karşılaşmaktadır. Bu yüzden kadının evlendikten sonra evliliğini sürdürmesi gerekliliği ve içinde bulunduğu toplumsal yapının boşanma olgusuna karşı çıktığı söylenebilmektedir. 
Ayrıca cinsiyet açısından ele alındığında bir katılımcının "kadın dediğin kadın gibi olmal yani naif, zarif olmall. Nasıl yaratılmışlarsa öyle kabul edilmeli..." (K11, 40 yaşında, evlenme yaşı 15) şeklinde ifadesinde yer aldığı üzere gibi biyolojik yapısı nedeniyle kadın, erkekten daha güçsüz, kırılgan ve naif görülmektedir. Diğer yandan, anlatının devamında aynı katılımcı kadın; "Yaşadı̆̆ım çevrede kadın mutlaka cinsel objedir ondan sonra kullanılması gereken bir materyaldir. İste evlensin, çocuk yapsin, evinde otursun, herhangi bir hak talep etmesin. Bizim toplumumuz genelde böyle bir kadın ister yani..." (K11, 40 yaşında, evlenme yaş1 15) ve yine başka bir katılımc1; "Vallahi kadını köle olarak görüyorlar sadece. Kadını afedersin doğuran ve çocuğu büyüten kişi olarak görüyorlar. Yani tavuk kuluçkası olarak düşünüyorlar. Sanki kadın orada tavuk, kendi yavrularına bakıyor gibi görülüyor. Kadın işte kalkıp çocuk doğuracak, doğuracak bunlara bakacak. Yani böyle işte maalesef burada kadın çok hor görülüyor. "(K6, 27 yaşında, evlenme yaşı 16 ) ifadeleriyle kadınlığı açıklamaya çalışmışlardır. $\mathrm{Bu}$ anlatılardan hareketle katılımcıların kadınlık betimlemelerinde cinsel bir obje olarak görülen kadınların ev içerisindeki konumları; eşle cinsel yaşantı, hamilelik, çocuk sahipliği, çocuk bakımı ve ev işleri ile sınırlıdır. Yani özel alanla ilgili rolleri gerçekleştirmek kadının doğuştan sahip olduğu bir yeteneği olarak görülmektedir. Bu doğrultuda, toplumsal açıdan çocuk bakımı ve annelik rolünün gerçekleştirilmesi, ev işlerinin yapılması, eş ile cinsel ilişki içerisinde olması, gerektiği yerde erkeklerin de işlerini yapabilmesi, eşin ihtiyaçlarını karşılaması, sosyal yaşamının olmaması ve yaşamının ev ile sınırlandırılması kadınlardan beklenen roller arasında yer almaktadir.

Kadınların kamusal alanda yer almaları konusunda toplumsal kalıplara eleştirel yaklaşımlar da bulunmaktadır. Bu doğrultuda kadın katılımcılar, toplumsal açıdan kısıtlama ve ataerkil düzen içerisinde bir baskılama olmadığı sürece her türlü işi yapabilecekleri hatta özel alan rolleri ile kamusal alan rollerini bir arada yürütebileceklerini belirtmişlerdir. Yiğit (2015) 'in yaptığ çalışmada da benzer sonuçlar elde edilmiştir. Buna göre ataerkil düzenin ve toplumsal cinsiyet kalıp normlarının erken evliliklerle birlikte kadınları daha da sınırlandırdığı, eğitim haklarını elinden aldığı, onların edilgen bir yaşam sürmesine ek olarak toplum içerisinde eşitsizliklere ve baskılara maruz bırakılmalarına neden olduğu ifade edilmektedir. Ayrıca araştırmada, kadınların sadece özel alanla sınırlı rolleri gerçekleştirmesi gerektiğini belirten katılımcılar da bulunmaktadır:

"Bir kadın ev işi de yapar, çocuklarına da bakar, eşine de bakar, mesleği varsa gider mesleğini de yapar. Yani kadın okumuşsa her işi de yapar, elinden her iş gelir kadının. Çoğu kadın şoförlük bile yapar. Erkekler dışlamadığı sürece kadın her işi yapabilir." (K3, 28 yaşında, evlenme yaşı 17)

"Kadın dediğin evinde oturmalı bence. Sadece ev hanımı olmalıdır."

(K7, 19 yaşında, evlenme yaşı 15)

Kamusal alanda yer almanın yanı sıra, eğitim sahibi olmak da günümüzde önem teşkil etmektedir. Eğitimin toplumsal açıdan kadının rolü olarak tanımlanıp tanımlanmadığına bakıldığında kadın katılımcılar toplumsal açıdan kadınların eğitimine 1lımlı yaklaşılmadığını belirtmektedirler. Çünkü kadınların yeri özel alan ile konumlandırılmaktadır. Ataerkil zihniyet kadınların çalışmasına karşı çıkmakta, kadınların eğitim seviyesinin yükselmesiyle birlikte onların kamusal alanda yer alacakları endişesi görülmektedir. Ancak son yıllarda bu bakış açısında da bir değişme olduğu ve kız çocuklarının okutulması noktasında önemli bir ilerleme kaydedildiği vurgulanmaktadır. Geçmiş zamanlarda kadının eğitimi bir tehlike unsuru olarak görülmekte ve kadınların bilinçlenmesinden endişe duyulmaktayken günümüzde kadınların eğitimine önem verilmektedir.

"Eskiden okutulmuyordu, hatta kızların okutulmasını çok kötü karşılardı ama şimdi tam tersi kızların okumasına daha çok önem veriliyor. Daha çok destekçi olunuyor, daha çok yardımcı oluyorlar. 
Yani bayanların okuması için anneler de, babalar da hep beraber destek veriyorlar. Bunun değişmesinin sebebi, kadınların daha çok ezildiğini görmeleri. Yani bakıyorlar, kadın okumazsa erken evlendiğinde çok fazla eziliyor. Onun mutsuzluğunu görünce, kendileri de mutsuz oluyorlar. O mutsuzluğu yaşamak istemedikleri için klz çocuklarını daha çok okutuyorlar, eğitimlerine önem veriyorlar.” (K6, 27 yaşında, evlenme yaşı 16)

"Eğitim konusunda bakış açısı son yıllarda daha iyi. Benim 19931994 yılından bahsediyorum ben ilk ehliyet aldığım zaman koca bir aşiret çalkalandı diyebilirim. Büyük bir edepsizlik olarak görüldü ki nastl ehliyete başvurabilir ve ben o zaman bulunduğum bölgede bölge birincisi olmuştum ehliyette ve bu bana müthiş bir özgüven kazandırdı bana ve okumaya başladım. Her okuduğum yıl bana çok büyük bir sorun yaşattı aile tarafinda. İşte eşimin ailesi tarafindan... Hatta çok iyi hatırlıyorum, açık ögrretim kitaplarımı gidip yakardı, saklardı ki çalışmayayım sınavlardan kalayım. Sinavlara götürmezdi. Kadının eğitimi şu an için çok çok rahat. Ama o yıllarda müthiş bir edepsizlik, müthiş bir başıboşluk olarak görülürdü. Çünkü kadını eğitmek erkeği çok zor duruma koyacaktı. " (K11, 40 yaşında, evlenme yaşı 15)

Tüm bunlar, toplumsal cinsiyet açısından ele alındığında kadınlık ve erkeklik rollerinin farklı şekillerde kurgulandığını göstermektedir. İfadelerden de anlaşılacağı üzere erken evlilik yapan kadın katılımcılar tarafından cinsellik ve namus kavramları kadınla özdeşleştirilmektedir. Kadın hem erkeğin namusunun bir temsili, hem cinsel bir obje, hem de bir meta olarak görülmektedir. Aynı zamanda kadın özel alanla sınırlı tutularak, onlardan ev işleri, eş olma, çocuk bakımı gibi rol ve sorumlulukları üstlenmesi beklenmektedir. Ataerkil zihniyet ve geleneksellikten kaynaklı cinsiyet odaklı toplumsal yaşama yönelik eleştiriler olsa da kadın katılımcılar tarafından toplumsal cinsiyet rol ve sorumluluklarının kabulü söz konusu olmakta doğallaştırılarak sergilenmekte, gerçekleştirilmektedir. Kardam ve diğerlerinin (2005) 'Türkiye'deki Namus Cinayetlerinin Dinamikleri' üzerine yaptığ kavramı kadın, kadın bedeni, cinselliği üzerinden açıklanmış ve kadınların da namusu cinsellik üzerinde tanımladıkları ve bu durumu içselleştirdikleri belirtilmiştir. Buna göre Kardam ve diğerlerinin elde ettikleri sonuçlar araştırmamızı destekler niteliktedir.

\section{Annelik Rolü ve Çocuk Bakımı}

Kadınlık rolleri üzerinde en çok vurgulanan rol, annelik rolü (Ricci, 2013; Bal, 2014) olmaktadır. Bu yüzden annelik ve çocuk bakımı konusu geniş bir şekilde ele alınmaya çalışılmaktadır. Annelik, kadın katılımcılar tarafından farklı şekillerde değerlendirilmektedir. Kırk altı yaşında bir katılımcının "Annelik güzel bir duygudur. Çocuklarına bakmak, onlarla ilgilenmek anneliği oluşturan en önemli şeydir. Anne olmak emek vermek, fedakâr olmaktır. Yeri geldi mi kendin yemezsin çocuklarına yedirirsin. Anne olmak dinen de kutsaldır. Cennet annenin ayaklarının altındadır. Burada bile annenin ne kadar önemli olduğunu ııı görebilirsin... Kadın çok önemlidir." (K2, 46 yaşında, evlenme yaş1 16) şeklindeki ifadesinde anneliğin 'kutsal bir görev' olması ve 'yaşanabilecek en güzel duygu' olması yönüne vurgu yapmaktadır. Dini açıdan da 'cennetin annelerin ayaklarının altında olması' şeklinde değerlendirmeler yapılmaktadır. Katılımcılara göre annelik, fedakarlık gerektirmekte ve pek çok şeyden vazgeçilmesini mecbur kılabilmektedir. Çocuğun yol gösterici haritası ve koruyucusu olarak konumlanan kişi annedir. Annelik, çocuğun her türlü bakımını ve sorumluluğunu üstlenebilmek, şefkatli, sevgi dolu ve ilgili olabilmektedir.

Anık ve Barlin'in (2017), Balıkesir'de erken evlilikler üzerine yaptığı bir çalışmada elde ettikleri sonuçlar araştırmamızı destekler niteliktedir. Buna göre kız çocuklarının erken 
evlilikle birlikte çocuk yaşta eş olmanın yanı sıra annelik rolünü üstlendikleri belirtilmektedir. Bu durum kadın katılımcılar tarafından şu şekilde ifade etmektedir:

"Kadın çocuklarina örnek olur, yol gösterir. Anne olmasa çocuklar eğitimli olamaz. Çünkü ıll anne hep evdedir, baba hep dlşardadır. Anne çocuğun her şeyiyle ilgilenir. Çocuklara yemeğini verir, altını değiştirir, emzirir, hastalanınca yanında durur. Çocuk her şeyi ilk annesinden ögrenir. Anne bir şeyi yanlış yaparsa çocuk da ona bakar aynı yanlışı yapar. Anne nasıl adım atarsa çocuk da öyle adımlar atar. Yani anne çok önemlidir.” (K2, 46 yaşında, evlenme yaş1 16)

"Annelik şefkat demektir. Çocuğuyla ilgilenen, ona doğruyu öğreten kişidir. Anne çocuğun dünyasıdır... (K14, 44 yaşında, evlenme yaşı 16)

"Ya eğitim evde başllyor sonuçta. Gün boyu anne çocukla beraber. En yakın iletişim kurduğu kişi ilk önce anne. Ĕ̆itim anne de başliyor. Anne ne verebiliyorsa, çocuk da iyi kötü onu allyor. Ama akşamdan akşama gördüğü bir baba örneği var, ama anne gün boyu yanında. $O$ yüzden bence çocuğun eğitimindeki en büyük detay annedir. Bu yüzden annenin de eğitimli olmast ve ahlaki dĕgerlere sahip olmast gerekiyor..." (K9, 38 yaşında, evlenme yaş1 15)

Anlatılarda da görüldüğü üzere babanın kamusal alandaki rolü nedeniyle çocuk bakımında çok yetkin olmaması, çocuk bakımının annenin sorumluluğunda olması, onun sevgi, sayg1, terbiye gibi temel değerleri anneden alması ve her türlü rolü annenin üstlenmesi olarak belirtilmektedir. Bu da kadına gerek biyolojik gerekse de toplumsal açıdan yüklenilen cinsiyet rolleri ile ilgili olmakta ve çocuk bakımı kadının sorumluluğu olarak görülmektedir. Kadının yeri daha önce de belirtildiği gibi özel alanla sınırlandırıldığı için çocuk bakımı ve sorumlulukların üstlenilmesi de kadının özel alan içerisindeki konumuna bağlanmaktadır.

Çocuk bakımında hem kadın hem de erkeğin önemli olduğunu ifade eden kırk dört yaşında bir katılımeı "Çocuğun bakımında yani aslında kadın yok şunu yapar, yok bunu yapar diyemem. Her ikisi de çocuğu yetiştirirken çok önemli. İşte zaten ben de o yüzden boşanmadım eşimden. Çocuklarımın anne babadan ayrl yetişmesini istemedim. Kadın da, erkek de çocuğun güvenli bir evde büyümesinde çok önemlidir. Kadın eğer çalışmıyorsa evdeki işleri halletsin, çocuğun evdeki ihtiyaçlarını gidersin. Baba da hem evde hem dışarda çocuğu için çalışsın." (K14, 44 yaşında, evlenme yaşı 16) diyerek kadının özel alan içerisindeki konumu ve erkeğin ise kamusal alandaki konumunu vurgulamaktadır. Dolayısıyla her ne kadar hem kadın hem de erkek önemli olarak değerlendirilmiş olsa da çocuk söz konusu olduğunda bakım sorumluluğu açısından kadının daha önemli görüldüğünü söylemek mümkündür.

Kadınların kendi anlatılarında vurgulananlardan da anlaşılacağ temel olarak kadın ile özdeşleştirilmektedir. Ancak kadının çocuk bakımını gerçekleştirmesinde de toplumsal açıdan birtakım beklentiler bulunmaktadır. Bu beklentiler kadınların erken yaşta evlilik yaptıkları hususunu yok saymakta ve kadının çocuğa iyi bir şekilde bakabilmesi beklentisi dikkat çekmektedir. Kadınlardan çocuğunun her türlü bakımını üstlenebilen, çocuk bakımını eksiksiz yerine getirebilen, çocuğun her şeyine yetişen ve fedakâr olabilen yani toplumsal açıdan ideal olarak tanımlanan anne modeline uyması beklenmektedir. Oysaki erken evlilik gerçekleştiren kişilerin kendileri çocuk yaştadır ve çocuk yaşta çocuk bakımının gerçekleştirilmesi onlar için ağır bir yük olmaktadır. Ayrıca yeni bir aileye dahil olma sürecinin zorluklarının yanı sıra çocuk bakımına yönelik bir bilgisizlik durumu da söz konusudur. Bu durum katılımcıların aile içerisinde şiddetin farklı türlerine maruz kaldıklarını da göstermektedir: 
"Eşimin ailesi benim yaşımın küçük olmasından dolayı çocuğa bakamayacă̆ımı beceriksiz, olduğumu düşündüler. Annelik ve ev kadını olmam konusunda yetersiz olduğumu düşündüler. Ama aksini gördüler. Benden çocuklarlyla ilgilenen, ilgi ve şefkat gösteren bir anne olmamı beklediler. Ama kendi ailem de eşim de çocuklara bakma konusunda bana destek oldular. Yani eşim benden hem onunla ilgilenmemi hem de çocuklarla ilgilenmemi bekledi. Tabi hepsini bana bırakmadı. Kendi de bana anlayış gösterdi ve yardımcı oldu." (K1, 30 yaşında, evlenme yaşı 17)

“... Derdi kocam, bebek ağllyo mamasını ver, emzir, uyut falan, yardımcı olmadı. Sanki eve köle almışlar gibi davranmamı bekliyorlardl. Tüm sorumluluk bana yüklenmişti. Kocam hep onun ailesine kölelik yapmamı istedi, zorla yaptırdı bana. Yani eşim ve eşimin ailesi benden dört dörtlük anne olmamı beklediler. Yaşım küçüktü bilmiyodum bir şey. Çocuk her ă̆ladı̆̆ında susturmaya çalışıyodum. Eşimin ailesi beceriksiz diyolardı bana. İşte benden çocuğun altını değiştirebilen, akşamları uyumayan çocuğun başında bekleyen bi anne olmamı istiyorlardl. Kendimden kısıp hep çocukla ilgilenmemi istiyolardı ne de olsa anne fedakar olmall. Çocuğa ben bakamayınca kaynanam çocuğu benden alıp mama yediriyodu. Onlar iyi bir anne olmamı bekliyolardı ama işte küçüktüm anlamıyodum ki annelik ne." (K2, 46 yaşında, evlenme yaşı 16)

"Eşim, ailemdeki herkes, benden çocuklarının her şeyiyle ilgilenen bir anne olmamı istiyordu. Ama ben beceremiyordum. Ancak üçüncü çocuğumda anne olabilmiştim. Anne gibi fedakar olamiyordum. Uykum gelince çocuk ağlasa bile uyumaya devam ediyordum işte. Kaynanam anlatıyordu, gösteriyordu her şeyi. Allah ondan razl olsun. Illk bebeği kucă̆ıma verdikleri zaman çok korkmuştum. Ona nasıl meme verecektim, hiç bilmiyordum. Kaynanam gösterdi. Ama bebeğim memeyi emmeye başladığında ben çı̆̆lık atmış ă̆lamıştım. Çok korkmuştum. Sanki beni yiyecek gibi gelmişti. O yüzden onların istediği gibi bir anne olmadım." (K14, 44 yaşında, evlenme yaşı 16)

Toplumsal beklentilerin varlığıyla birlikte annelik, erken yaşta evlenen kadınlar üzerinde belirli etkiler doğurmakta ve hayatlarının daha da farklılaşmasına neden olmaktadır. Bir katılımcının "...Çocuğa nasıl bakılır bilmiyordum. Çocuk büyüdükten sonra anladım anneliği, onsuz yaşayamayacağımı. Bide oğlum yedi aylık dünyaya gelmişti ilk doğumumda, ona bakmayı beceremiyordum. Kucağıma almaya korkuyordum."(K2, 46 yaşında, evlenme yaşı 16) şeklindeki ifadesinde de görüldüğü üzere çocuk bakımına yönelik bilgisizlik ve bilinçsizlik kadınların hayatlarını daha da zorlaştırmaktadır. Evlilik sonrasında kadınların çocukluktan çıkıp olgun bir şekilde çocuk bakımı, eş olma ve ev işlerini gerçekleştirmeleri beklenmektedir.

Kadın katılımcılar içerisinde aldatılan ve çocuktan dolayı eş ile eşin ailesine muhtaç olduğu düşünüldüğü için şiddet görmeye başladığını belirten katılımcılar bulunmaktadır. Dolayısıyla çocuk sahipliği ile kadın, eşin ve eşin ailesinin bir mülkü gibi konumlanmış ve daha da arka plana itilmiştir. Çocuk sahipliğinden sonra yaşanan diğer bir zorluk ise maddi imkanların yetersizliğidir. Maddi imkanların yetersizliği nedeniyle çocuk bakımının gerçekleştirilmesi ve çocuğun ihtiyaçlarının karşılanmasında zorluklar yaşanmıştır. Kadınların anlatılarında bu durumu eleştirdikleri ve içinde bulundukları yaşam koşullarını kabullendikleri gözlenmektedir: 
"Hayatım daha çok kötü oldu eşimle. Eşim daha çok dişarıya yöneldi. Afedersin kadin klz peşinde gitti. Ben sanıyordum ki çocuk doğurdukça hayatım düzene girer, eşim bana bă̆lanır. İnan ki öyle bir şey yok daha çok perişan oldum. Her şey daha kötü oldu, daha çok kaybettim." (K5, 40 yaşında, evlenme yaş1 17)

“...çocuk olması bana zorluk yaratmadl. Istemeden, sevmeden yapmış olduğum bir evliliğim olduğu için çocuğumun olması benim hayatımı o kadar değiştirdi ki yani çocuğa bağlandım ben açıkcası. Yani onun olmasıyla ben gerçekten eve bağlandım. Yani benim için evlilik denilince eşittir çocuk aklıma gelir. ... Valla bana yapılan muamele bir çocuğa yapılan muameleydi. Ama 30 yaşındaki bir insandan beklenen şeyleri yapmamı bekliyolardı. Ya mesela 16 yaşındaydım büyük değildim öyle. Ama her şeyi yapmamı bekliyorlardı. Işste ev işi, yemek, çocuk bakımı, işte eşinle ilgilenmen, onun ütüsü, çamaşırı. Yani 30 yaşındaki bir kadının olgunluğuyla bekliyorlardı. Ama bana yapılan tavır ve konuşma şekli de çocuğa yapılan bir tavırdı...” (K9, 38 yaşında, evlenme yaşı 15)

"Kendimden vazgeçtim. Artık çocuklarıma adadım kendimi. Yokluk içinde büyütmek çok zor. Ben çocuklarıma kardeşlerimin çocuklarının verdiği giysilerle büyüttüm. Çünkü alamıyordum." (K10, 41 yaşında, evlenme yaşı 16)

"Çocuk olduktan sonra hayatım daha kötüye gitti. Bir nevi karşı taraf çocuk olduktan sonra diyor ki bu kız artık bize iyice bağland, bir yere gidemez, çocuk için sesini çıkaramaz falan. Olaylar daha sarpa sarıyor, kötüleşiyor. Bu sefer şiddet başlıyor. Şiddet başladiğında da bu defa yapacak bir şey yok, ya birakıp gideceksin ya da susup oturup kaderine razl olacaksin. Ama bence kaderine razı olmamak lazım." (K13, 32 yaşında, evlenme yaşı 15)

Kadın katılımcılar çocuk sahibi olunca bir takım zorluklar yaşamalarına rağmen çocuk bakımında belirli unsurların önemini vurgulamaktadır.

“...çocukların eğitimli olmasına özen gösteriyorum. Çünkü klz çocuklarının okuması, bilinçli olması önemli. En azından kızlar okursa erken yaşta evlenmek istemezler. Her şeyin farkında olurlar." (K4, 36 yaşında, evlenme yaşı 17)

"En başta çocuğumun yalan konuşmamasını, doğru olmasını. Çocuklarımın saygl, sevgi çerçevesinde yetişmesini isterim. Çocuklarımla arkadaş gibiyim. Onlarla sırrımı paylaşırım onları dinlerim." (K8, 35 yaşında, evlenme yaşı 17)

"Çocuğumu yetiştirirken en çok Allah'a inançlı olmasina ve merhametli, vicdanl olmasina önem verdim. Onlara dinimizi anlattım, ahlaklı olmasını istedim. Yani en çok da okumalarını istedim ve çok şükür de öyle yetiştirdim. Hepsi çok güzel okuyorlar.” (K14, 44 yaşında, evlenme yaşı 16)

$\mathrm{Bu}$ doğrultuda kadın katılımcılar, kız çocuklarının eğitimine önem vermektedir. Nitekim erken yaşta evlenen ya da zorla evlendirilen kadın katılımcılar kız çocuklarının da kendileri gibi bu duruma maruz kalmaması için okumaları gerektiğini ve okumaları durumunda erken yaşta evlenmelerinin engellenebileceğini ifade etmişlerdir. Ayrıca kadın katılımcılar açısından çocuk yetiştirmede en çok vurgulanan nokta, onları ahlaklı ve terbiyeli yetiştirme çabalarıdır. Dolayısıyla çocukların dürüst olmaları, saygılı olmaları, merhametli olmaları gibi hususların önemsendiği söylenebilmektedir. Katılımcılar içerisinde çocukların 
kendileri ile her türlü paylaşımda bulunmalarını sağlamak amacıyla onlarla arkadaş gibi olmaya önem verdiklerini belirtenler de bulunmaktadır. Diğer yandan çocuk yetiştirmede önem verilen diğer bir husus dini açıdan da çocukların bilinçlendirilmesi ve bu noktada çocuk yetiştirmede din faktörünün de belirleyici ve önemli olduğudur.

\section{Toplumsal Açıdan Erkeklere Yönelik Bakış Açısı ve Erkeklik Rolleri}

İnsanlar kadın ya da erkek cinsiyeti ile doğmalarına karşılık içinde bulunduğu toplumun kültürüne özgü yetiştirilerek toplumsal cinsiyetlerine özgü roller çerçevesinde büyürler ve sosyalleşirler (Powell and Greenhaus, 2010, s. 1012). Buna göre çalışmada erkeklik rolleri konusunda öncelikle kadın katılımcıların kendi bakış açılarıyla bir erkeklik kurgulamasının nasıl olduğu görülmek istenmiştir. Bu bağlamda kadın katılımcıların erkeklik kurgulamalarına bakıldığında, erkeğin babalık ve eş olma rolüne vurgu yapıldığı görülmektedir. Buna göre, erkeğin iyi bir baba, iyi bir eş olması, kamusal alanda yer alarak ailenin ihtiyaçlarını karşılayabilmesi ve aileye bakabilmesi, ailesine sahip çıkması gerekmektedir. Bu haliyle kadın katılımcılar erkeğe aile içerisinde koruyuculuk, bakım ve otorite sahipliği rollerini yükleyerek erkeği birincil konumda görmektedirler. Katılımcılar, toplumsal açıdan erkeklerin birincil konumunu vurguluyor olsalar da kendileri de erkeklere yükledikleri roller ile toplumsalı doğallaştırmış görünmektedirler. Çünkü onların bakış açısına göre de erkeklerin kamusal alanda yer alma, eve, eşe, çocuklara bakabilme, koruma ve toplumsal beklentiler doğrultusunda bir erkek olabilme gibi rolleri gerçekleştirmeleri gerekmektedir. Böyle bir durumda, bazı katılımcılar açısından her ne kadar kadın-erkek eşitliğine yönelik söylemler de olsa kadını ikincilleştiren hem toplum hem de kadının kendisi olmaktadır. Dolayısıyla kadın katılımcıların erkeklik kurgulamalarında da toplumsal cinsiyet algısının baskın geldiği söylenebilmektedir:

"Erkek dediğin sadık olmalı, güvenilen biri olmalıdır. ...Erkek dürüst olmalıdır. Merhametli olmalıdır, kadın gibi fedakâr olmalıdır. Erkek sahiplenebilen, koruyucu olmalıdır. Gerektiği yerde karısının, kızının namusunu korumalıdır. ...Çevrede erkekler de hep bi üstünlük şeysi var. Yani işte ben üstünüm hep bi liderlik savaşı var aralarında. Kadınlara karşı da hep bir güç gösterisi var. İşte ben erkeğim istediğimi yaparım, sen kadınsın yapamazsın. Çünkü erkekler soyu ilerletiyor, yeri geldiğinde çocuklarını ailesini koruyo. Erkek evin üstünde durur, klz evlenir gider ama erkek kendi ailesine bakar. Erkek her anlamıyla kadından önde görülür." (K2, 46 yaşında, evlenme yaş1 16)

"Erkek evine bakabilmeli, eşine saygll sevgili olmalıdır. Erkek her zaman için ailesine dürüst olmall, sadık olmalıdır. Gerektiği zaman eşine destek olmalıdır, erkek dışarıda çalışarak eve para getirmelidir, evin dışarıdaki ihtiyaçlarını karşılamalıdır. Yani erkek çalışmazsa para kim getirir ki eve? Erkek çalışacak ki eve para gelsin. Çoluğun çocuğun ihtiyaçları karşılansın. Bunlar hep erkeğin görevleridir. Erkek dediğin bunları yapmalıdır. Bir erkek anca bunları yaparsa erkektir. " (K4, 36 yaşında, evlenme yaşı 17)

"Erkek dediğin destekçi olmall, her anlamda eşine, evine sadık olmalıdır... Burada erkekleri horoz gibi görüyorlar. Nasılsa horoz kümesin sahibi ise, erkek de kadınların sahibi olarak görülüyor. $O$ erkek olmazsa bir kadın dışarı çıkamaz. Erkek olmazsa hele ki mesela bir dul bayan, dul olduğu için eşinden boşanmış ya da eşinin ölmüş olduğunu farz edelim tek başına dışarı çıkamaz, tek başına bir şey yapamaz. Ona kötü gözle bakılır. Erkek bayanın yanında olmadı̆̆ zaman kadına kötü gözle baklyorlar. Bunun nedeni ise bu toplumun 
erkeklerin baskın olduğu bir toplum olmasından kaynaklanmaktadır.

Yani erkek topluluğudur." (K6, 27 yaşında, evlenme yaş1 16)

Kadın katılımcıların toplumsal açıdan erkeklere yönelik bakış açısında hakim olan düşünce erkeğin erkek olmasından dolayı her türlü eyleminin meşru sayılmasıdır. Kırk yaşında bir katılımcının "Erkeğe şöyle bir bakış açısı var bizim toplumumuzda; erkek yapar... Yani erkek evlenebilir, erkek aldatabilir, erkek dövebilir, bir erkek, erkek çocuğunu kayırabilir, erkek dışarıda her şeyi yapar. Ama kadın evinden dışarı başını çıkaramaz. Çok namuslu, çok ahlaklı olmalıdır bizim toplumumuz böyle... Erkek yapmaz, erkek emreder ve kadın sadece yapmak zorundadır. Tabi bu benim fikrim değil. Ben hep diyorum ya eşlik derken kadın erkek eşitliğini şu anlamda demiyorum, yardımcı olmak anlayışla karşılamak, kadına yardım etmek, çocuk bakımında destek olmak, kadının yükünü hafifletmek yani bunlar insani şeyler. Bunları kılıbıklık veya iş yapıyor anlamında değil insani olarak değerlendirmek lazım. "(K11, 40 yaşında, evlenme yaşı 15) ifadesinde de görüldüğü üzere, erkeğin eşini aldatması, eşe yönelik şiddet içeren eylemlerde bulunması gibi durumlar normalleştirilmektedir. Dolayısıyla toplumsal açıdan kadınlara yönelik bir ayrımcılık yapıldığı ve kadın ile erkeğin eşit tutulmadığı söylenebilmektedir. Diğer yandan, kadın katılımcılar da toplumsal açıdan erkeğin eş ve babalık rolü, kamusal alanda yer alması, evin geçimini, ihtiyaçlarını sağlayabilmesinin önemli görüldüğünü ifade etmişlerdir. Özel alanda ise toplumsal açıdan erkeğin her hangi bir sorumluluk almadığı, özellikle kadının da kamusal alanda yer alması durumunda özel alandaki sorumlulukların erkek ve kadın tarafından yardımlaşarak yerine getirilmesi gerektiği belirtilmiştir. Bu durumu katılımcıların erken yaşta evlilikle birlikte edindikleri deneyimleri ve anlatıları desteklemektedir:

"Erkek evde bir iş de yapmaz. Yer, içer, yatar. Her şeyi kadından bekler. Zaten ev işi kadının işidir. O yüzden erkek evde kadın işi yapmaz. Yani çamaşır, bulaşık yıkamaz, yemek yapmaz. Bunlar kadının işidir. Erkeğin yapabileceği iş dĕ̆ildir. Kadın bu işleri yapmak için dünyaya gelmiş zaten." (K4, 36 yaşında, evlenme yaşı 17)

"Burda erkekler her haltı yapsın ama yine erkektir gözüyle baklyorlar. Erkek ne yapsa doğru yapar anlayışı var. Erkek namussuzluk da yapsa 'Erkektir, çapkındır' diyorlar. Ama işte bunu anlamıyorum ben. Kadın aynı şeyi yapsa adı namussuza çıkar, kötü gözle bakarlar. Ama aynı durum erkeklerde olsa 'Çapkındır' deyip geçiyorlar... Erkek de çallşlyorsa eğer eve para getirsin, güler yüz göstersin anlayışl olsun yeterli, bir iş yapmasa da olur. Ama her ikisi de çalışıyorsa o zaman evde işler bölüşülebilir. Yani eve erken gelen yemek yapsın, diğeri gelince bulaşık yıkasın. Hayat zor kadın-erkek birbirine destek olmall. Tabi ben bunlardan hiç birini kocamdan görmedim ki, her şeyi kendi başıma yapıyorum ben." (K14, 44 yaşında, evlenme yaşı 16)

Anlatılardan hareketle, erkeğin kamusal alanda daha önemli bir yer teşkil ettiği söylenebilir. Kadın katılımcılar tarafından erkeğin kamusal alan içerisindeki her türlü işi yapabileceği belirtilmektedir. Çünkü erkeğin yaptığı işin niteliğinden ziyade belirli bir gelir elde edebilmesi, ailenin ihtiyaçlarını karşılayabilmesi, aileyi kimseye muhtaç etmemesi ve kimseye muhtaç olmaması önemli görülmektedir. Burada, toplumsal cinsiyetin biyolojik yanına özgü bir değerlendirme de yapılarak erkeğin kadından daha güçlü olması nedeniyle erkeklerin kadınlardan daha ağır işleri yapabilecekleri de belirtilmektedir:

"Erkek her işi yapabilir. O da kadın gibi inşaatta çalışabilir, çoban olabilir, pilot olabilir, mimar olabilir. Yani erkek aklina gelebilecek her işi de yapabilir. Bence kadın işi de yapabilir erkek. İşte ev 
temizleyebilir, çocuk bakabilir, yemek yapabilir, bulaşık yıkayabilir. Evde kadının yaptığı ne iş varsa ıı erkek de yapabilir.” (K2, 46 yaşında, evlenme yaşı 16)

"Bir erkek de her işi yapar ama helal yoldan yapması önemlidir. Erkek yeri geldi mi bakıcılık bile yapar. Öyle kadın erkek şu işi yapsin, bunu yapsin diyemem. Ĕger her ikisinin de çalışması gerekiyorsa her işi de birlikte yapabilirler. Çünkü hayat zor, ne bileyim geçim çok zor. Ekmek aslanın midesinde resmen." (K14, 44 yaşında, evlenme yaşı 16)

Kadın katılımcıların erkeklerin eğitimi noktasındaki düşüncelerini ise iki grupta toplamak mümkün olmaktadır. Birinci grupta katılımcılar, erkeklerin eğitim sahibi olmasının gerekli olmadığını belirtmişlerdir. Çünkü eğitimden ziyade erkeklerin bir işte çalışmaları ve evin geçimini sağlayabilmeleri daha önemli görülmektedir. Diğer bir ifadeyle eğitimli olmaktan ziyade meslek sahibi olmanın daha önemli olduğu vurgulanmaktadır. Çünkü toplumsal açıdan erkek, kamusal alan ile özdeşleştirilmektedir.

"Erkekler okusa yine bizim oğlumuzdur diyorlar. Erkekler okusun ki ileride bize faydası dokunsun diyorlar." (K3, 28 yaşında, evlenme yaş1 17)

"Erkeklerde eğitime çok önem vermezler. Aslında yani düzgün bir işi olsun. Onun için daha önemlidir. Çünkü evine bakabilmesi için eğitimden çok düzgün bir işinin olması önemlidir. Çünkü erkek eve para getirendir. Para getirebilmesi için meslek sahibi olmasl gerek yani bu meslek sahibi olmak sadece ĕgitimle ilgili değildir. İnşaat işçisi olup da eve parayı da getirebilir. Yeter ki erkek eve para getirsin, ailesine bakabilirsin. " (K4, 36 yaşında, evlenme yaşı 17)

İkinci gruptaki katılımcılar ise gerek kız çocukları gerekse de erkek çocuklarının eğitim sahibi olmaları gerektiğini ifade etmektedir:

"Maddiyat varsa erkeği okutur, sonuna kadar götürür bazı insanlar. Bazılart ise, çocuğum mesleğini eline alsın diye elinden geleni yapar. Yani bi kisitlllık yok erkek için. Erkek her zaman okutulur. Çünkü erkek önemlidir.” (K1, 30 yaşında, evlenme yaşı 17)

"Erkek de okumalıdır. Kız-erkek ayrımı yok. Ikisi de okumalıdırlar. Meslek sahibi olmalarl, memur olmaları önemli." (K10, 41 yaşında, evlenme yaşı 16)

"Yani kadın da erkek de bu devirde okuyor zaten. Artık herkes daha bilinçli, işte bu telefonlar, internet felan çıktı ya, teknoloji baya gelişti. Herkes okuyor artık. Kadın erkek fark etmiyor. En uç köylerde bile artık insanlar çocuğunu okutuyor." (K14, 44 yaşında, evlenme yaşı 16)

Burada erkeğin birincil konumu nedeniyle eğitimli olmasının öneminin yanı sıra erkeklerin kamusal alan içerisinde daha iyi koşullar içerisinde yer almaları da eğitimli olmalarına bağlanmıştır. Hem kız hem de erkek çocuklarının eğitimlerine önem verilmesi ve eğitim sahibi olmaları, toplumsal değişim ve teknolojinin gelişimiyle de açıklanmıştır. Dolayısıyla eğitim konusunda toplumsal açıdan bir bilinçlenme sağlandığı söylenebilmektedir.

\section{Babalık Rolü ve Çocuk Bakımı}

Çocuk bakımında annelik rolü kadar babalık rolü de önemlidir. Bu bağlamda erkeklerin sahip oldukları önemli rollerden biri de babalık rolüdür (Werrren, Gross ve Shine, 1980). Kadın katılımcılar tarafından babalık tanımlamaları farklılaşmaktadır. On dokuz yaşında bir katılımcı ise "Baba dışardadır bir şey bilmez ki. Çocuğa hep annesi bakar. Baba 
eve eşya getirir, para getirir." (K7, 19 yaşında, evlenme yaşı 15) diyerek erkeğin kamusal alandaki rolleri ve kadının özel alandaki rollerine bağlı olarak erkeğin babalık konusundaki bilinçsizliğini dile getirmektedir. Böylelikle çocuk sahipliği, annelik ile özdeşleştirilen bir durum olmaktadır. Kadın katılımcılardan bazıları ise babalık ve anneliği çocuk yetiştirme açısından birbirini tamamlayan unsurlar olarak görmekle birlikte annelik gibi babalığın da fedakârlık gerektirdiğine ve vazgeçilmez olduğuna vurgu yapmaktadırlar:

"Babalık, anneye yardımcı kişidir. Baba evin maddi-manevi her şeyini karşılayan, alan kişi. Erkek eve para getirmezse evdekiler aç kalır. Erkeğin çalışıp karısına ve çocuklarına bakması gerekiyo. Babalık budur bence." (K2, 46 yaşında, evlenme yaş1 16)

"Babalık o evin ihtiyaçlarını gören, maddi manevi işlerine koşan kişidir. Yani nasıl anlatsam ă̆acın yaprakları var ya baba ă̆aç gibidir. Sevgi verdikçe, saygı verdikçe o ăgacın yaprakları büyür. Fakat erkekler çok geç olgunlaştığı için iki üç çocuktan sonra, asıl babalı̆̆ın ne olduğunu o zaman anlıyorlar. Baba olmak eşinin çoluğunu çocuğunu kimseye muhtaç etmeyen, maddi manevi her anlamda ailesine destek veren kişidir. Baba olmazsa çocuk da işte sahipsiz kalır. Yani baba olmak, bir annenin yapabileceğinin yarıs kadar da olsa yapmasıdır. Çocuğa da, aileye de, işe de hepsine karşı sorumluluğunu yerine getirmesidir. Baba da büyük bir sorumluluk alır. Mesela en başta baba maddi sorumluluk alır. Baba çalışır, getirir, anne onu çevirir, evlatlarına güzel bir gelecek sağlar. Anne bunların hepsini yapabilir ama baba sadece maddi anlamda en çok etki eder. Onun maddiyatı olmazsa çocuklara destek olmazsa o anne yarım kalır. Babanın da desteği çok önemlidir evlilikte, ama bir anne kadar önemli değildir bence." (K6, 27 yaşında, evlenme yaşı 16)

Babalık tanımlamalarında ifade edildiği üzere erkeğin "evin reisi" konumunda olması da dikkat çekmektedir. Baba rolündeki erkek, birincil konumda yer almakta ve kadın ile çocuklar ikincilleştirilmektedir. Birincil konumu ile baba, evin geçimini sağlaması, eşe ve çocuklarına sahip çıkması gibi sorumlulukları yerine getirmesi gereken kişi olarak betimlenmektedir. Bu bağlamda kadın katılımcıların babalık tanımlamalarında dikkat çeken nokta, babalığın erkeklik rolleri ile tanımlanmış olmasıdır. Buna göre, baba kamusal alandaki rolleriyle evin, eşin ve çocukların her türlü ihtiyaçlarını karşılaması gereken kişi olarak ifade edilmiştir. Bu durum, Sancar (2009, s. 120-121)'ın babalığın annelikten farklı bir şekilde çocuk doğurmaması nedeniyle çocukla biyolojik olarak açık bir ilişkisinin olmaması, babalığın sosyo-kültürel açıdan annenin ve çocuğun geçimini sağlamak için kamusal alanda yer alma zorunluluğu gibi nedenlerle çocukla anne-çocuk ilişkisindeki gibi bir ilişki kuramaması şeklindeki ifadesiyle açıklanabilmektedir.

Çocuk bakımı konusunda her erkek aynı derecede etkin olamamaktadır. Bazıları çocuklarıyla ilgilenme, zaman geçirme, oyun oynama vb. gibi her faaliyetiyle yakından ilgilenirken bazıları bu konularda daha kısıtlı davranış sergileyebilmektedir (Atmaca Koçak, 2004). Çalışmada, çocuk bakımında kadınının yanı sıra erkeğin de önemli olduğu görülmüştür. Kadın katılımcılara göre anne ile baba, çocuk bakımında birbirlerini tamamlayıcı olarak belirtilmektedir. Bunun yanı sıra, katılımcıların babalık tanımlamalarında olduğu gibi çocuk bakımında da erkeğin kamusal alandaki rolü baskın olmakla birlikte evin ve çocuğun her türlü ihtiyacının karşılanmasına yönelik vurgu yapılmaktadır. Ancak babanın rolü sadece maddi anlamda çocuğun ve evin ihtiyaçlarının karşılanması ile sınırlı değildir. Erkek evrensel olarak soyun devamını sağlama, aileyi koruma ve geçindirme rollerine sahip olsa da (Gilmore, 1990), çalışmada baba rolündeki erkeğin aynı zamanda, çocuğa sevgi 
vermesi, çocukla ilgilenmesi ve çocuğun gelişmesine yardımcı olması da önemli görüldüğü bulgusu elde edilmiştir:

"Baba da anne kadar önemlidir. Ama baba dışarıda olduğu için evde hep anne ilk ilgilenir çocukla. Baba eve para getirir, çocuğun maddi ihtiyacı varsa onu alır. İşte çocuğu okutur, kitaplarını, çantasını alır falan. Babanın çocuğa sevgisini göstermesi de önemlidir. Baba çocuk için anneye yardımcı olmalıdır." (K2, 46 yaşında, evlenme yaş1 16)

"Eğitim konusu olsun saygl, sevgi olsun her türlü ihtiyacını karşılamalıdır. Bu sadece çalışıp da para getirmek değildir. Onun da çocuklarıla ilgilenmesi, çocuklarına karşı kendi sorumluluklarının olduğunu bilmesi gerekir. Bu da çocuğun özgüveninin olmasını güçlendirir. Bu konuda babaya çok fazla görev düşer.” (K8, 35 yaşında, evlenme yaşı 17)

"Erkek, çocuğu büyütürken çok önemlidir. Anne kadar baba da çocuğa örnek oluyor. Yaptı̆̆ her davranış, ettiği her söz çocuğa örnek oluyor. Baba evin direğidir. Çocuk hastalaninca babası götürür doktora ilaçlarını alır. Ben işe gittiğimde eşim bakar çocuklara.” (K7, 19 yaşıında, evlenme yaşı 15)

Kadın katılımcılar, kadının olduğu gibi erkeğin de her türlü davranışı ile çocuğa rol model olduğunu ifade etmektedirler. Dolayısıyla sosyalleşme sürecindeki çocuğun okul öncesi ilk eğitimini aileden aldığı göz önüne alındığında annenin yanı sıra babaya da babalık rollerinin gerçekleştirilmesi ve çocuk bakımı konusunda önemli bir görevler düşmektedir.

\section{Değerlendirme ve Sonuç}

Ataerkil toplumun geleneksel değerlerinin varlığını geçmişte olduğu gibi bugün de sürdürmesi günümüz toplumlarında kadın ve aile ile ilgili sorunların tartış1lıyor olmasına kaynaklık etmektedir. Ataerkil sistem ve geleneksel aile yapısı içerisinde kadının statüsü, kadın ve erkek arasındaki cinsiyete dayalı rol farklılıkları, aile içi kadına yönelik şiddet, erken evlilikler gibi konular bugün de önemini korumakta ve kadın konusu ön plana çıkmaktadır.

Araştırmada, erken evlilik gerçekleştiren kadınların toplumsal cinsiyete yönelik algıları ele alınmaktadır. $\mathrm{Bu}$ amaçla, çalışma Ağrı ilinde evliliklerini 18 yaş altında gerçekleştiren 15 kadın katılımcıyla bir nitel yöntem tekniği olan derinlemesine görüşme tekniği kullanılarak gerçekleştirilmiş ve elde edilen bulgular doğrultusunda değerlendirmeler yapılmıştır. Araştırma, erken evlilik gerçekleştiren kadınlar ile yapılmış olması açısından önem taşımakta ve kadınların ifadeleri doğrultusunda erken evliliklerde hem kadın hem de erkeklerin toplumsal cinsiyet rollerinin değerlendirilmesi bağlamında literatüre katk1 sağlayacağı düşünülmektedir.

Araştırma kapsamında elde edilen veriler değerlendirildiğinde erken evliliklerde toplumsal cinsiyetin hem biyolojik hem de toplumsal olarak kurgulandiğ ulaşılmıştır. Oakley (1998) cinsiyet ile kadın ve erkeğin biyolojik farklılıklarını; toplumsal cinsiyetle ise biyolojik farklılıkların yanı sıra toplumsal olarak kadın ve erkeğin farklı algılanmaları ile doğan eşitsizlikleri belirttiğini söylemekte iken bu çalışmada da bu tanıma paralel cinsiyetin biyolojik farklılıklar temelli toplumsal olarak kurgulandığı görülmüştür. Dolayısıyla Sabuncuoğlu (2006)'nun yaptığı toplumsal cinsiyet tanımlaması da araştırmaya uygun düşmektedir. Buna göre, toplumsal cinsiyet, dişil ve eril kavramları ile kadın ve erkek arasındaki toplumsal rol farklılıklarına işaret etmektedir. Eril ve dişillik ise toplumsal ve kültürel yapı ekseninde belirlenmektedir. Araştırmada da toplumsal ve kültürel yapının etkisi açık bir şekilde görülmektedir. Toplumsal ve kültürel yapının etkisi altında yapılanan toplumsal cinsiyet rolleri, toplumdaki kadın ve erkekler tarafından bazı yönleriyle eleştirilse de içselleştirilmekte ve doğallaştırılarak gerçekleştirilmektedir. 
Toplumsal cinsiyet açısından kadınlık rollerine bakıldığında Navaro (1997) kadınların edilgen, yumuşak, uyumlu, güçsüz, çaresiz, bağımlı olduklarını belirtmiştir. Bu araştırmada da kadınlık rollerinin bu özellikler çerçevesinde kurgulandığı görülmüştür. Kadınların kendilerini değerlendirmelerinde toplumsal cinsiyet kalıplarının ve dolayısıyla toplumsal baskının belirleyici olduğu sonucuna varılmıştır. Buna göre, kadınlar kendi rollerini özel alan ile sınırlı roller çerçevesinde tanımlamışlar ve temel olarak ev işlerinin gerçekleştirilmesi, eşe sadık olmak, eşe bağlı olmak, çocuk bakımının gerçekleştirilmesi ve çocuğa dair tüm sorumlulukların üstlenilmesi olarak belirtmişlerdir. Toplumsal açıdan ise kadınlar, sahip oldukları cinsiyetleri ile tanımlandıklarını belirtirlerken cinsellik ve namus vurguları ön plana çıkmaktadır. Kadınlar için boşanmak, utanılacak bir durum olarak görülmektedir. Çünkü toplumsal açıdan boşanmış olmak yadırganmakta ve kadınların böyle bir durumda güçsüz oldukları algısının oluşmasıyla namusları için bir tehdit unsuru olmaktadır. Bu yüzden, kadınlar boşanma sonrasında medeni durumlarını gizlemek zorunda kalabilmektedir. Kadınlık rolleri içerisinde en çok vurgulanan ise kadının annelik ve çocuk bakımına dair rolleridir. Annelik ve çocuk bakımı, bir kadınla eş tutulan şeylerdir. Kadının rollerinin özel alan ile sinırlandırılması da buna imkan tanımaktadır. Annelik, hem kadınlar hem de erkekler açısından fedakarlık ve şefkat ile özdeşleştirilmiştir. Çocuk bakımında bazı katılımcılar tarafından erkeğin de yardımcı konumda olması gerektiği vurgulanırken bazı katılımcılar açısından ise sadece kadının rolü üzerinde durularak kadının özel alandaki yeri nedeniyle çocuk bakımını üstlenmesi gerektiği belirtilmiştir. Diğer yandan anne, çocuk için bir rol model olarak betimlenmiştir. Ancak evliliklerin erken yaşlarda gerçekleştirilmiş olması özellikle annelik, çocuk bakımı ve ev içi roller konusunda zorluklar yaşanmasına neden olmuştur.

Toplumsal cinsiyet açısından önemli olan diğer rol de erkeklik rolleridir. Selek (2014) erkeklerin güç, sahip olma, geçindirme, yönetme, dayanıklılık gibi niteliklerle donatıldığını belirtmektedir. Navaro (1997) da erkeklerin daha sert ve etkin olduklarını, bağımsız ve hükmedici olduklarını belirtmiştir. $\mathrm{Bu}$ araştırmada da kadınlar tarafından erkekler, bu özellikler çerçevesinde tanımlanmış ve rolleri bu eksende şekillendirilmiştir. Buna göre, bir erkeğin kamusal alan içerisinde yer alarak ailenin geçimini karşılaması beklenmektedir. Bir erkeğin ailenin geçimini sağlayabilmesi için her türlü işi namusu ile yapması gerektiği vurgulanmaktadır. Diğer yandan, ailenin namusunu korumak da erkeğin önemli bir rolü olarak görülmüştür. Erkeğin en çok vurgulanan diğer bir rolü ise babalık ve çocuk bakımıdır. Babalık ve çocuk bakımı konuları, bazı katılımcılar tarafından erkeğin kamusal alan rolleri nedeniyle erkeğin bilgisizliği noktasında değerlendirilmiş ve erkeğin evin geçimini sağlaması, çocuklara iyi bir gelecek sunma çabasında olması gibi unsurlar vurgulanmıştır. Bazı katılımcılar açısından da erkeğin ev içerisinde her türlü işte olması gerektiği gibi çocuk bakımında da kadına yardımcı konumda olması ve çocuklar ile her türlü paylaşımın sağlanması, çocuklara iyi bir gelecek sunulması gibi noktalarda değerlendirilmiştir. Ayrıca evliliklerinin erken yaşlarda gerçekleşmiş olması nedeniyle toplumsal açıdan erkeklerin beklenen bu rolleri gerçekleştirmelerinde zorluklar yaşadıkları belirtilmiştir. Tüm bunlar, erkeklerin de kadınlar gibi toplumsal cinsiyete dair rol kalıplarıyla kuşatılmış olduklarını göstermektedir.

Kisacası, toplumsal cinsiyet rolleri kadın ve erkek arasında her alanda farklılık yaratmaktadır. Edilgen bir konumda bulunan kadınların rolleri özel alanla sınırlı tutulmakta, ev işleri, annelik rolü, çocuk bakımı, eş ile ilgili sorumluluklar gibi birçok görevi kadının gerçekleştirmesi beklenmektedir. Erken evlilik yapan kadınlara göre etkin bir konumda bulunan erkeklerin rolleri ise kamusal alana dayandırılmakta, erkeğin evin geçimini sağlaması, namus koruyuculuğu görevini gerçekleştirmesi, babalık rolü ve kısmen de olsa çocuk bakımı gibi görevleri gerçekleştirmeleri gerektiği vurgulanmaktadır. Ayrıca erken evlilik gerçekleştirmiş olmak özellikle çocuk bakımı ve eş olma rolü açısından zorluklara 
sebep olmaktadır. Ancak günümüzde erken evlilik yapan kadınlar tarafından toplumsal cinsiyete özgü rol ve sorumluluklar konusunda bir bilinçlenme söz konusuysa da yine de ataerkil zihniyete özgü kadın-erkek arasındaki rol ve sorumlulukların paylaşımı noktasında bir eşitsizlik söz konusudur. Dolayısıyla kadınlar tarafından sosyo-kültürel yapının dayattıkları hala benimsenmeye devam edilmekte ve toplumsalın dayattıkları doğallaştırılarak uygulanmaktadır. 


\section{Kaynakça}

Anık, M. ve Barlin, R. (2017). Türkiye'de Çocuk Gelinler Sorunu: Balıkesir Örneği. İnsan ve Toplum Bilimleri Araştırmaları Dergisi, 6(3), 1827-1841.

Arslan, Y. (2015). Oyundan Dügüne Hayatlar: Güneydoğu'da Çocuk Gelinler. İstanbul: Belge.

Atmaca Koçak, A. (2004). “Türkiye'de Babaların Şimdiki Durumu, Baba Destek Programı Değerlendirme Raporu”. İstanbul: Boğaziçi Üniversitesi, 1-65.

Aydemir, E. (2011). "Evlilik Mi Evcilik Mi? Erken ve Zorla Evlilikler Çocuk Gelinler." Uluslararası Stratejik Araştırmalar Kurumu Sosyal Araştırmalar Merkezi, USAK Rapor No: 11.

Bal, S. (2014). Reklamların Eskimeyen Yüzü "Muhteşem Annelik": Anneler Günü Reklamları Örneği. Ankara Üniversitesi İlef Dergisi, 1(2), 59-85.

Birleşmiş Milletler. (1989). Birleşmiş Milletler Çocuk Haklarına Dair Sözleşmesi. http://cocukhaklari.barobirlik.org.tr/dokuman/mevzuat_uamevzuat/birlesmismill etler.pdf

Boran, P., Gökçay, G., Devecioğlu, E. ve Eren, T. (2013). Çocuk Gelinler. Marmara Medical Journal, 26, 58-62. doi:10.5472/MMJ.2013. 02751.1

Burcu, E., Yıldırım, F., Sırma, Ç. S. ve Sanıyaman, S. (2015). Çiçeklerin Kaderi: Türkiye'de Kadınların Erken Evliliği Üzerine Nitel Bir Araştırma. Bilig Türk Dünyası Sosyal Bilimler Dergisi, 73, 63-98.

Calp, Zeynep Kevser. (2014). Rakamlarla Çocuk Evlilikler. Çocuk Gelinler: Evcilikten Evliliğe, Ed. Hasan Şen, Ankara: Detay.

Creswell, J. W. (2013). Nitel Araştırma Yöntemleri-Beş Yaklaşıma Göre Nitel Araştırma ve Araştırma Deseni. Mesut Bütün ve Selçuk Beşir Demir (Çev. Ed.) Ankara: Siyasal Kitabevi.

Diyaplıoğlu, M., Yıldırım, F. ve Purutçuoğlu, E. (2017). Kız Çocuklarının Erken Evliliklerini Önlemede Erkeklerin Rolü. Sosyal Politika Çalışmaları Dergisi, 17(38), 95-114.

Dökmen, Z. Y. (2004). Toplumsal Cinsiyet Sosyal Psikolojik Açıklamalar. Ankara: Sistem.

Gezer Tuğrul, Y. (2018). Erken Yaşta Evlendirilen Kadınların Evlilik Süreçleri, Deneyimleri ve Sonraki Yaşamları Üzerine Nitel Bir Çalışma. Sosyoloji Notları, 1(2), 2-38.

Gilmore, D. D. (1990). Manhood In The Making: Cultural Concepts of Masculinity. London: Yale University.

Günay, G. ve Bener, Ö. (2011). Kadınların Toplumsal Cinsiyet Rolleri Çerçevesinde Aile İçi Yaşamı Algılama Biçimleri. Türkiye Sosyal Araştırmalar Dergisi, 153(153), 157-171.

Kandiyoti, D. (1988). Bargaining with Patriarchy. Gender and Society, 2(3), 274-290.

Kara, B. (2015). Değişen Aile Dinamikleri Açısından Erken Yaşta Evlilikler Sorunu ve Toplumsal Önemi. Süleyman Demirel Üniversitesi İktisadi ve İdari Bilimler Fakültesi Dergisi, 20(2), 59-72.

Kardam, F., Alpar, Z., Yüksel, İ. Ve Ergün, E. (2005). Türkiye'deki Namus Cinayetlerinin Dinamikleri. Ankara: Koza. 
Marshall, G. (1999). Sosyoloji Sözlügü. Osman Akınhay \& Derya Kömürcü (Çev.). Ankara: Bilim ve Sanat.

Navaro, L. (1997). Tapınağın Öbür Yüzü: Kadınlar ve Erkekler Üzerine. İstanbul: Varlık.

Oakley, A. (1998). Women's Studies In British Sociology: To End At Our Beginning, The British Journal of Sociology, 40(3), 441-470.

Orçan, M. ve Kar, M. (2008). Türkiye'de Erken Yaşta Yapılan Evlilikler Ve Risk Algısı: Bismil Örneği. Sosyal Politika Çalışmaları Dergisi, 14(14), 97-111.

PLAN-UK (2011). Breaking Vows: Early And Forced Marriage And Girls' Education. https://plan-uk.org/file/breaking-vows-efm-3462225pdf/download?token=RlE5iobL

Powell, G. ve Greenhaus, J. (2010). Sex, Gender, and Decisions at The Family-Work Interface. Journal of Management, 36(4), 1011-1039.

Ricci, S. S. (2013). Essentials of Maternity, Newborn, \& Women's Health Nursing. 3rd edition. Wolters Kluwer Health,| Lippincott Williams \& Wilkins.

Sabuncuoğlu, A. (2006). Televizyon Reklamlarında Toplumsal Cinsiyet. (Yayınlanmamış yüksek lisans tezi). Ege Üniversitesi/Sosyal Bilimler Enstitüsü, İzmir.

Sancar, S. (2009). Erkeklik: İmkânsız İktidar-Ailede, Piyasada ve Sokakta Erkekler. İstanbul: Metis.

Selek, P. (2014). Sürüne Sürüne Erkek Olmak. İstanbul: İletişim.

Terzioğlu, F. ve Taşkın, L. (2008). Kadının Toplumsal Cinsiyet Rolünün Liderlik Davranışlarına ve Hemşirelik Mesleğine Yansımaları. C.Ü. Hemşirelik Yüksekokulu Dergisi, $12(2), 62-67$.

Turğut, M. ve Feyzioğlu, S. (Ed.) (2014). Türkiye Aile Yapısı Araştırması Tespitler, Öneriler. Ankara: T.C. Aile Ve Sosyal Politikalar Bakanlığı Aile Ve Toplum Hizmetleri Genel Müdürlüğü.

https://www.tuseb.gov.tr/enstitu/tacese/yuklemeler/ekitap/aile/60_aile_yapisi_arastirmasi_201 3.pdf

Türk Medeni Kanunu. (2001). Türkiye Cumhuriyeti. 4721 (8049-8210). http://www.mevzuat.gov.tr/MevzuatMetin/1.5.4721.pdf

Türkiye İstatistik Kurumu (TUİK). (2018). İstatistiklerle Çocuk, 2017. Sayı: 27596. http://www.tuik.gov.tr/PreHaberBultenleri.do?id=27596

United Nations Children's Fund (UNICEF). (2005). Early Marriage A Harmful Traditional Practice: A Statistical Exploration, A Statistical Exploration. New York: UNICEF. http://www.unicef.org/publications/files/Early_Marriage_12.lo.pdf

United Nations Children's Fund (UNICEF). (2012). A Note On Child Marriage. https://www.unicef.org/policyanalysis/files/Note_on_Child_Marriage.pdf

United Nations. (2000). World Marriage Patterns, 2000. Polulation Division-Department Of Economic And Social Affairs. www.un.org/en/development/desa/population/publications/pdf/family/marriage-patterns.pdf 
Werren, J. H., Gross, M. R. ve Shine, R. (1980). Paternity And The Evolution Of Male Parental Care. Journal of Theoretical Biology, 82(4), 619-631.

Yiğit, T. (2015). Feminist Sosyal Hizmet Yaklaşımı Bağlamında Ataerkil İdeoloji ve Erken Evlilikler. (Yayınlanmamış doktora tezi). Hacettepe Üniversitesi/Sosyal Bilimler Enstitüsü, Ankara.

Yüksel, H. ve Yüksel, M. (2014). Çocuk İhmali ve İstismarı Bağlamında Türkiye'de Çocuk Gelinler Gerçeği. Çankırı Karatekin Üniversitesi Sosyal Bilimler Enstitüsü Dergisi, 5(2), 124.

Yüksel-Kaptanoğlu, İ. ve Ergöçmen, B. A. (2012). Çocuk Gelin Olmaya Giden Yol. Sosyoloji Araştırmaları Dergisi, 15(2), 128-161. 